Review

\title{
Cellular Prion Protein: From Physiology to Pathology
}

\author{
Sei-ichi Yusa, José B. Oliveira-Martins ${ }^{\dagger}$, Yoshiko Sugita-Konishi and Yutaka Kikuchi * \\ Division of Microbiology, National Institute of Health Sciences, Tokyo, Japan; \\ E-Mails: s-yusa@nihs.go.jp (S.I.Y.); ykonishi@nihs.go.jp (Y.S.-K.)
}

$\dagger$ Current Address: Roche Diagnostics Deutschland GmbH, Mannheim, Germany; E-Mail: jose.martins@roche.com.

* Author to whom correspondence should be addressed; E-Mail: kikuchi@nihs.go.jp; Tel.: +81-3-3700-9496; Fax: +81-3-3700-9496.

Received: 30 September 2012; in revised form: 5 November 2012 / Accepted: 6 November 2012 / Published: 14 November 2012

\begin{abstract}
The human cellular prion protein $\left(\mathrm{PrP}^{\mathrm{C}}\right)$ is a glycosylphosphatidylinositol (GPI) anchored membrane glycoprotein with two N-glycosylation sites at residues 181 and 197. This protein migrates in several bands by Western blot analysis (WB). Interestingly, PNGase F treatment of human brain homogenates prior to the $\mathrm{WB}$, which is known to remove the $\mathrm{N}$-glycosylations, unexpectedly gives rise to two dominant bands, which are now known as C-terminal (C1) and N-terminal (N1) fragments. This resembles the $\beta$ amyloid precursor protein (APP) in Alzheimer disease (AD), which can be physiologically processed by $\alpha$-, $\beta$-, and $\gamma$-secretases. The processing of APP has been extensively studied, while the identity of the cellular proteases involved in the proteolysis of $\operatorname{PrP}^{\mathrm{C}}$ and their possible role in prion biology has remained limited and controversial. Nevertheless, there is a strong correlation between the neurotoxicity caused by prion proteins and the blockade of their normal proteolysis. For example, expression of non-cleavable $\mathrm{PrP}^{\mathrm{C}}$ mutants in transgenic mice generates neurotoxicity, even in the absence of infectious prions, suggesting that $\operatorname{PrP}^{\mathrm{C}}$ proteolysis is physiologically and pathologically important. As many mouse models of prion diseases have recently been developed and the knowledge about the proteases responsible for the $\mathrm{PrP}^{\mathrm{C}}$ proteolysis is accumulating, we examine the historical experimental evidence and highlight recent studies that shed new light on this issue.
\end{abstract}

Keywords: neurodegenerative disease; prion; proteolytic cleavage; $\mathrm{C} 1$ 


\section{Introduction}

Transmissible spongiform encephalopathies (TSE diseases) or prion diseases are all fatal neurodegenerative conditions that include scrapie in sheep, bovine spongiform encephalopathy (BSE) in cattle, chronic wasting disease (CWD) in cervids, and kuru, Gerstmann-Sträussler-Scheinker syndrome (GSS), sporadic, familial, and variant forms of Creutzfeldt-Jakob disease (CJD) in humans. The central dogma of prion biology is that the normal cellular isoform of prion protein $\left(\operatorname{PrP}^{\mathrm{C}}\right)$ encoded by the highly conserved single-copy gene Prnp [1] is post-translationally refolded into a partially protease resistant and $\beta$-sheet-enriched conformation (generally termed $\mathrm{PrP}^{\mathrm{Sc}}$ ) that is infectious [2]. However, neither the mechanism by which $\mathrm{PrP}^{\mathrm{Sc}}$ causes neuronal dysfunction during prion disease nor the normal function of $\operatorname{PrP}^{\mathrm{C}}$ is well defined. Although several functions have been suggested $[3,4,5,6,7]$, none of these has been shown to be associated with prion disease pathogenesis or prion replication.

The neurotoxicity caused by prions is not simply explained by loss of a normal functional activity of $\operatorname{PrP}^{\mathrm{C}}$, since mice lacking $\operatorname{PrP}^{\mathrm{C}}$ are healthy and fail to develop prion disease [8,9]. Aguzzi's group investigated whether prion pathology derived from neurotoxicity of $\mathrm{PrP}^{\mathrm{Sc}}$, by grafting neural tissue overexpressing $\operatorname{PrP}^{\mathrm{C}}$ into the brain of $\mathrm{PrP}^{\mathrm{C}}$-deficient mice which are resistant to prions [10]. The grafted tissues kept producing high levels of $\mathrm{PrP}^{\mathrm{Sc}}$ and induced localized infectivity after prioninoculation in those mice, while the surrounding $\operatorname{PrP}^{\mathrm{C}}$-deficient tissues showed no pathological changes and were not significantly damaged by $\operatorname{PrP}^{\mathrm{Sc}}$. These results indicate that normal host prion protein is necessary for $\mathrm{PrP}^{\mathrm{Sc}}$-induced neurotoxicity.

Additional studies addressed whether neurotoxicity and infectivity are two distinct phenomena. Collinge's group developed double transgenic mice in which $\operatorname{PrP}^{\mathrm{C}}$ is conditionally depleted in neurons after 9 weeks of age using the Cre-loxP system [9,11]. After prion inoculation of these mice, they initially suffered from development of clinical disease, but suddenly recovered from the disease and reversed spongiform neuropathology and behavioral abnormalities at around 9 weeks, even when brains of the mice contained high levels of $\mathrm{PrP}^{\mathrm{Sc}}$. Furthermore, Chesebro's group established transgenic mice expressing prion protein lacking the glycosylphosphatidylinositol (GPI) membrane anchor to prevent the prion proteins from localizing on the surface of cells [12]. These mice accumulated abnormal protease-resistant $\mathrm{PrP}^{\mathrm{Sc}}$ in their brains after prion inoculation, and the brains were physically damaged by $\mathrm{PrP}^{\mathrm{Sc}}$ amyloid plaques, but no clinical signs of disease were observed after 1 to 2 years compared to that seen in the non-Transgenic ( $\mathrm{Tg}$ ) control wild-type mice after 140 to 160 days. Thus, whatever the physiological function of $\operatorname{PrP}^{\mathrm{C}}$, it has become increasingly clear that expression of $\operatorname{PrP}^{\mathrm{C}}$ at the cell surface is necessary to mediate the full toxicity induced by $\operatorname{Pr} \mathrm{P}^{\mathrm{Sc}}$.

The uncoupling of neurotoxicity and infectivity is a growing concept in the prion field [13]. Collectively, $\operatorname{PrP}^{\mathrm{Sc}}$ that is major constituent of prions can propagate using $\operatorname{PrP}^{\mathrm{C}}$ as a substrate and then $\mathrm{PrP}^{\mathrm{Sc}}$ may cause neuronal cell death using membrane bound $\mathrm{PrP}^{\mathrm{C}}$ as a detonator. How this occurs is currently unknown, however. 


\section{Normal cellular prion protein, $\operatorname{PrP}^{\mathrm{C}}$}

Three Nobel Prizes have been awarded for seminal work performed in the prion field. Daniel Carleton Gajdusek received the award in 1976 for the discovery of "slow virus" that is now known as prion disease. Stanley B. Prusiner subsequently received the award in 1997 for the discovery of "prion" as the sheep scrapie agent and introduction of the "protein only hypothesis", which stated that misfolded proteins are the infectious agents that cause prion diseases. Finally, Kurt Wüthrich received the award in 2002 for his contributions to the use of NMR to determine three-dimensional structures of proteins and nucleic acids in solution, including unraveling the structure of prion proteins using this technique.

According to the widely accepted "protein-only hypothesis" by Prusiner, proteinase resistant protein, $\mathrm{PrP}^{\mathrm{Sc}}$, is infectious. Early studies by Weissmann's group surprisingly demonstrated that $\operatorname{PrP}^{\mathrm{Sc}}$ is an abnormal isoform of host-encoded cellular prion protein $\left(\operatorname{PrP}^{\mathrm{C}}\right)[1,14]$. Since then, many scientific efforts have been performed to address the normal function of $\operatorname{PrP}^{\mathrm{C}}$, but the suggested physiological functions of $\operatorname{PrP}^{\mathrm{C}}$ do not completely explain all phenomena seen in prion diseases, and further research is needed. Several of these elements have been discussed in excellent recent reviews $[15,16,17]$. Here, we briefly elaborate on the processing of $\operatorname{PrP}^{\mathrm{C}}$, involving its normal metabolism.

$\operatorname{PrP}^{\mathrm{C}}$ is encoded on the short arm of human chromosome 20 (20q13) as $16 \mathrm{~kb}$ single copy PRNP gene and the open leading frame (ORF) is encoded on exon 2, which facilitates the cloning of the ORF by polymerase chain reaction (PCR) directly from genomic DNA. The human prion gene PRNP encodes a 253-residue precursor protein (see Figure 1). The first $22 \mathrm{~N}$-terminal residues are posttranslationally removed during transport to the cell surface. The last $23 \mathrm{C}$-terminal residues are excised after the addition of the glycosyl phosphatidylinositol (GPI) anchor. Thus, mature $\operatorname{PrP}^{\mathrm{C}}$ consists of 208 residues. As $\mathrm{PrP}^{\mathrm{C}}$ is variably glycosylated at two asparagine residues (N181 and N197), it exists as un-, mono- and di-glycosylated species.

When Wilfried W. de Jong's group compared PrP coding sequences in 26 mammalian species [18], they noted that a hydrophobic region in the middle of $\operatorname{PrP}^{\mathrm{C}}$ is perfectly conserved, suggesting that the region is functionally important for $\operatorname{PrP}^{\mathrm{C}}$. This hydrophobic core $(\mathrm{HC})$ region is immediately adjacent to the putative cleavage site of $\operatorname{PrP}^{\mathrm{C}}$, which is enriched in charged residues (Figure 1), designated the charged cluster (CC) region. The putative cleavage site has been commonly referred to as the $\alpha$ cleavage site.

Until more recently, the existence of the truncated form of $\operatorname{PrP}^{\mathrm{C}}$ was not widely recognized by many prion biologists, since western blot analysis for brain homogenates or cell lysates showed several bands, which were attributed to differential glycosylation. 
Figure 1. Diagrammatic representation of protein structure of normal cellular prion proteins. Based on the knowledge of physiological processing of prion protein $\left(\mathrm{PrP}^{\mathrm{C}}\right)$, it is likely that mature $\operatorname{PrP}^{\mathrm{C}}$ (residues from 23 to 253), N-terminal (N1) (23 to 110), C-terminal (C1) (111 to 253), and anchorless $\operatorname{PrP}$ (23 to 230) may exist in normal brains of humans. Anchorless PrP seems to be unglycosylated and non-cleavable at putative $\alpha$-cleavage site. The minimum sequence that causes spontaneous neurodegeneration when deleted in mice is shown in red. The additional open leading frame for anchorless PrP is underlined. SP, signal peptide; PC, positively charged region; CC, charged cluster region; HC, hydrophobic core region.

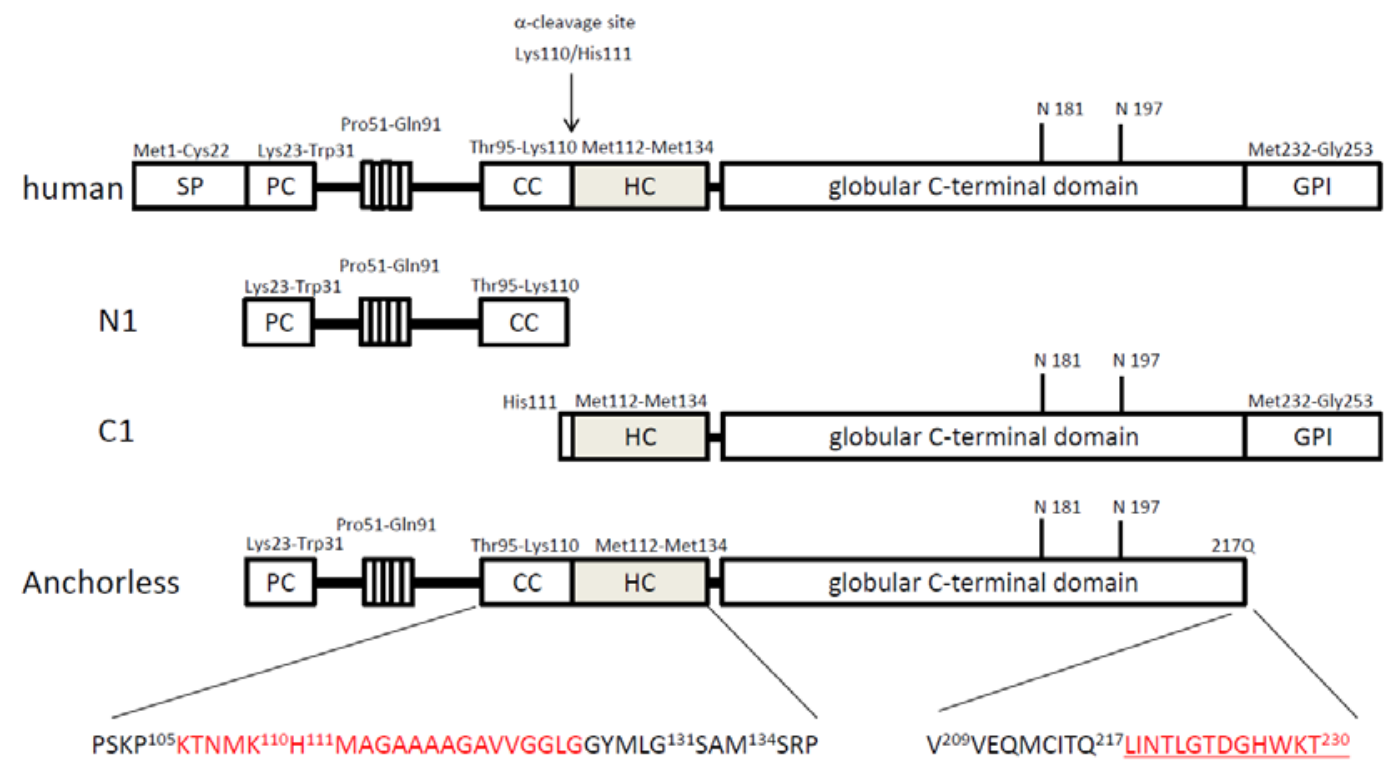

The discovery of the truncated form of $\mathrm{PrP}^{\mathrm{C}}$ can be traced back to the early 1990s, when Prusiner's group characterized $\mathrm{PrP}^{\mathrm{C}}$ from Syrian hamster brain [19]. They found two $\mathrm{PrP}^{\mathrm{C}}$ forms designated $\mathrm{PrP}^{\mathrm{C}}$ $\mathrm{I}$ and $\mathrm{PrP}^{\mathrm{C}}$-II which appeared to be generated from $\operatorname{PrP}^{\mathrm{C}}$-I by limited proteolysis of the $\mathrm{N}$-terminus, as confirmed by epitope mapping with different antibodies. Spontaneous degradation during the purification procedure was ruled out, since various protease inhibitors failed to alter the detection of the two protein forms. The same group further characterized $\operatorname{PrP}^{\mathrm{C}}-\mathrm{II}$ and concluded that $\operatorname{PrP}^{\mathrm{C}}-\mathrm{II}$ appears to lack the putative $\alpha$-helical domain (codons 109-122), which is likely to be necessary for $\mathrm{PrP}^{\mathrm{Sc}}$ formation. They also identified that chymotrypsin-like activity is a candidate mechanism by which a $\sim 9 \mathrm{KDa}$ fragment is proteolytically excised from the N-terminus of $\operatorname{PrP}^{\mathrm{C}}$ [20].

In 1995, Gambetti's group examined $\operatorname{PrP}^{\mathrm{C}}$ metabolism in more detail. The group characterized the PrP forms present in normal and pathological human brains and in neuroblastoma cells [21]. They demonstrated that a $\mathrm{COOH}$-terminal fragment of $\mathrm{PrP}^{\mathrm{C}}$, which was named " $\mathrm{C} 1$ ", is found in normal and CJD brains, as well as in human neuroblastoma cells. $\mathrm{C} 1$ turned out to have alternative N-termini starting at either His-111 or Met-112 using epitope mapping and radiosequencing. Thus, it seems that $\mathrm{C} 1$ contains at least the $\mathrm{HC}$ region (amino acids 112-133). Interestingly, both $\mathrm{PrP}^{\mathrm{C}}$ and $\mathrm{C} 1$ seem to be anchored to the cell membrane, since both are mostly recovered in the membrane fraction and are released after treatment with phosphatidylinositol-specific phospholipase C (PIPLC) [21]. These data provide supporting evidence that $\mathrm{Cl}$ is not a degradation product generated during experimental procedures, as suggested by others $[14,19]$. 
In 1993, Harris's group investigated chicken brain and murine neuroblastoma cells transfected with the chicken homologue of $\operatorname{PrP}^{\mathrm{C}}$ [22]. Chicken $\operatorname{PrP}^{\mathrm{C}}$ was demonstrated to undergo two cleavages as part of its normal metabolism. One product is a secreted form of full-length $\operatorname{PrP}^{\mathrm{C}}$, which is released from the membrane when the GPI-anchor is cleaved. Importantly, they also found a second truncated form that accounts for most of the surface-anchored molecules in transfected murine cells, indicating that the machinery to generate $\mathrm{C} 1$ is highly conserved between species. The $\mathrm{N}$-terminal cleavage fragment, termed N1, was found in medium from neuroblastoma cell cultures, as well as in chicken cerebrospinal fluid. We have also detected N1 fragments in the cell lysates of murine neuroblastoma N2a cells, although $\mathrm{N} 1$ is unstable even when stored at $-80^{\circ} \mathrm{C}$ in the presence of proteinase inhibitors, resulting in analysis having to be performed immediately to avoid degradation (unpublished data). Collectively, $\mathrm{PrP}^{\mathrm{C}}$ appears to have two physiological forms on cell surfaces; one is full-length and the other is the truncated $\mathrm{C} 1$ form, and both may have functions (Figure 1). Whether the secreted forms (GPI-cleaved PrP or N1) have physiological functions will require more detailed investigation in the future.

Interestingly, physiological anchorless prion protein may exist in humans due to alternative splicing of exon 2 of the PrP gene, which eliminates the GPI-anchor [23] (see Figure 1). Moreover, analysis of the transcriptome derived from zebrafish embryo mRNA present at 5.3 hours postfertilization (hpf) indicates splice variants of PrP-2 which lacks GPI-anchor [24]. Since the anchorless form is unglycosylated and unprocessed, the full-length anchorless $\operatorname{PrP}^{\mathrm{C}}$ may have physiological function in the absence of $\mathrm{N}$-linked glycosylation and without $\alpha$-cleavage [23]. Transgenic mice expressing artificial GPI-anchorless $\operatorname{PrP}^{\mathrm{C}}$ protein also showed that the exogenous anchorless $\operatorname{PrP}^{\mathrm{C}}$ is unglycosylated, reside in the cytosol, and is secreted [12]. However, the glycosylation status is controversial, since GPI-anchorless $\mathrm{PrP}^{\mathrm{C}}$ is fully glycosylated in different cell types [25]. Collectively, there are at least four forms of normal cellular prion protein; full-length GPI-anchored, N1, C1, and GPI-anchorless (Figure 1). None of the physiological functions of all these prion proteins has so far been clarified.

\section{Transgenic mouse models}

Prion diseases were originally thought to be caused by a kind of slow-virus, as suggested by Gajdusek. Subsequently, the nature of materials that cause prion diseases was hypothesized by Prusiner to be the $\mathrm{PrP}^{\mathrm{Sc}}$ protein, but not a virus. However, a new paradigm has appeared since normal cellular $\operatorname{PrP}^{\mathrm{C}}$ was found and examined. In 1998, Weissmann's group produced several truncated forms of $\operatorname{PrP}^{\mathrm{C}}$ to identify the regions necessary for its pathogenic conversion, since $\operatorname{PrP}^{\mathrm{C}}$-deficient mice are resistant to scrapie which is induced by mouse-adapted sheep prions [26]. Unexpectedly, they found that PrP lacking residues 32-121 or 32-134 caused severe ataxia and neuronal death limited to the granular layer of the cerebellum as early as 1-3 months after birth (Figure 2). Importantly, attempts to transmit disease with brains of these spontaneously ill mice failed, no PrP aggregation was found, and the introduction of a single copy of the wild-type Prnp allele $\left(\operatorname{PrP}^{\mathrm{C}}\right)$ rescued the phenotypes. Thus, $\operatorname{PrP}$ lacking residues 32-121 or 32-134 $(\Delta \mathrm{F})$ causes neuronal dysfunction irrespective of "infectious prions". Before this report, in 1990 Prusiner's group produced transgenic mice that have a leucine substitution at codon 101 (corresponding to P102L in human), which is the genetic basis of the human inherited prion disease, Gerstmann-Sträussler-Scheinker syndrome [27]. The mice also spontaneously 
developed prion diseases, showing spongiform degeneration, astrogliosis, amyloid plaques, and infectivity to other mice $[28,29]$. Based upon these reports, we have categorized the transgenic mouse models in two groups; one with the non-infectious " $\Delta \mathrm{F}$ phenotype", the other with the infectious "PrP ${ }^{\mathrm{Sc}}$ phenotype" (Table 1. Due to limited information some transgenic mice are excluded from these categories.

Weissmann's group produced mice expressing $\operatorname{PrP}$ with several amino-proximal deletions in addition to $\Delta \mathrm{F}$ (32-134) [26]. Some of these were normal, while others suffered from spontaneous neurological diseases which were non-infectious and did not generate protein aggregates. Interestingly, there was a strong correlation between the neurotoxicity caused by the truncated forms of $\operatorname{PrP}$ and the blockade of their proteolysis (see Figure 2). Wild-type $\operatorname{PrP}^{\mathrm{C}}$ (non-toxic), exogenous $\operatorname{PrP}^{\mathrm{C}}$ (non-toxic) (i.e. Tga20), $\Delta \mathrm{B}(32-80)$ (non-toxic), $\Delta \mathrm{C}(32-93)$ (non-toxic), and $\Delta \mathrm{D}(32-106)$ (non-toxic) all showed the appearance of $\mathrm{C} 1$ by western blot analysis and no cerebellar syndrome (Figure 2). On the other hand, $\Delta \mathrm{E}(32-121)$ (toxic) and $\Delta \mathrm{F}(32-134)$ (toxic) did not show detectable $\mathrm{C} 1$ and caused neurodegenerative symptoms, (however in the publication of the $\Delta \mathrm{F}$ mice it is difficult to judge $\mathrm{C} 1$ due to their similar size of $\Delta \mathrm{F}(32-134)$ and $\mathrm{C} 1)$. The absence of $\mathrm{C} 1$ in $\Delta \mathrm{F}(32-134)$ is also examined in an in vitro assay using the HpL 3-4 Prnp-deficient cell line [30], indicating that $\Delta \mathrm{F}$ is slightly larger than $\mathrm{C} 1$. The different phenotypes between the former (non-toxic) and the latter (toxic) are not simply explained by aberrant cellular localization of the truncated forms or by distinct expression levels, since all forms were shown to be expressed on the cell surface and the levels of transgene expression were comparable among the mice [26].

Figure 2. Schematic of $\operatorname{PrP}$ constructs and comparison of $\alpha$-cleavage. All constructs shown here are derived from murine $\operatorname{PrP}^{\mathrm{C}}$. The constructs were inserted into half genomic expression vectors, containing the promoter, 5'intronic, and 3'untranslated sequences of the murine prion protein gene [31,32]. All mice are $\operatorname{Prnp}^{0 / 0}$ background. Spontaneous neurodegeneration (Yes), $\mathrm{C} 1$ generation (Yes) are shown, according to the publications. *The sizes of $\mathrm{C} 1$ and exogenous PrP are similar so that it might be difficult to judge.

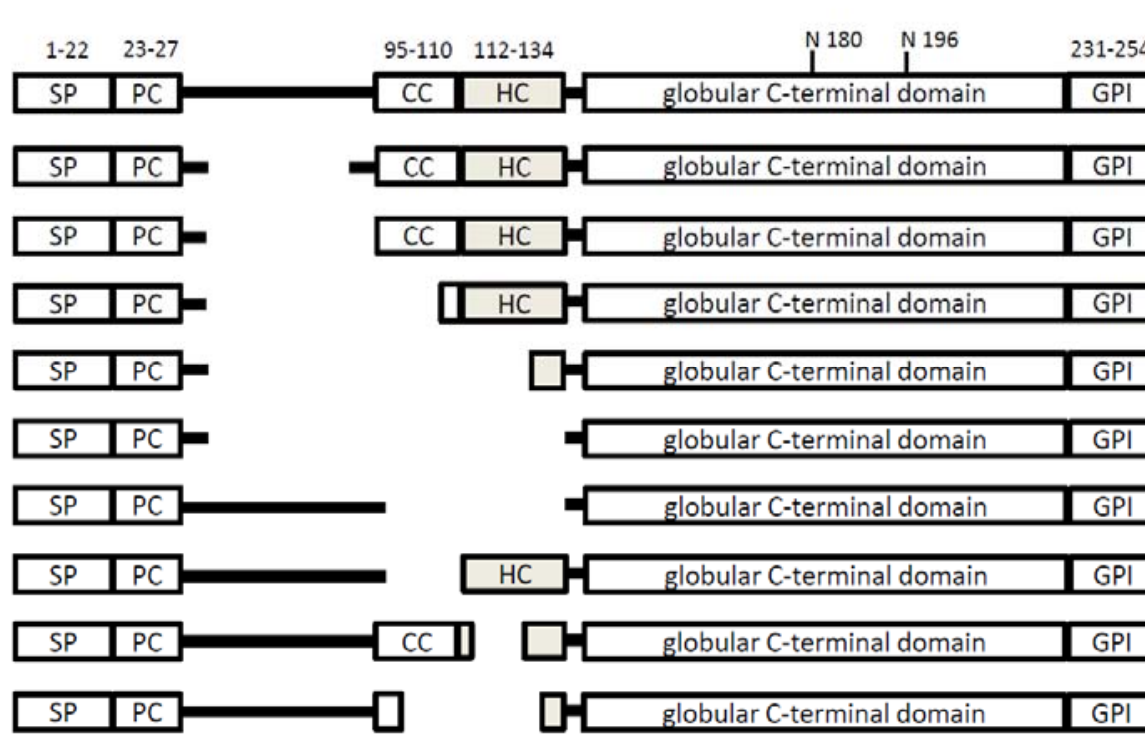

$\begin{array}{lcc}\text { Construct } & \text { Disease } & \alpha \text {-cleavage } \\ \text { Wild-type } & \text { No } & \text { Yes } \\ \Delta 32-80(\Delta \mathrm{B}) & \text { No } & \text { Yes } \\ \Delta 32-93(\Delta \mathrm{C}) & \text { No } & \text { Yes } \\ \Delta 32-106(\Delta \mathrm{D}) & \text { No } & \text { Yes } \\ \Delta 32-121(\Delta \mathrm{E}) & \text { Yes } & \text { No* } \\ \Delta 32-134(\Delta \mathrm{F}) & \text { Yes } & \text { No* } \\ \Delta 94-134(\Delta \mathrm{CD}) & \text { Yes } & \text { No } \\ \Delta 94-110(\Delta C \mathrm{CC}) & \text { No } & \text { Yes } \\ \Delta 114-121(\Delta \mathrm{pHC}) & \text { No } & \text { Yes } \\ \Delta 105-125(\Delta \mathrm{CR}) & \text { Yes } & \text { No }\end{array}$


Table 1. Transgenic mouse models with mutant prion proteins.

\begin{tabular}{|c|c|c|c|c|c|c|c|c|c|c|c|}
\hline Type & Designation & Human diseases & Copy number & Expression & $\mathrm{Prnp}^{+/+}$ & $\mathrm{Prno}^{0 / 0}$ & Onset & $\operatorname{PrP}^{\mathrm{Se}}$ & Transmission & $\mathrm{C} 1$ & Refferences \\
\hline \multirow{6}{*}{ 'PrP'se-type } & MoPrP-P101L & Familial; GSSP102L & 60 copies & 8 -fold & prion disease & ${ }^{5}$ Accelerated & $150-300$ days & ${ }^{3}$ PrPSc-like & Yes; P101L mice N & N.S. & $\begin{array}{l}\text { Hsiao et al. } 1990 \text { Science } 250: 1587-1590 . \\
\text { Hsiao et al. } 1994 \text { PNAS } 91: 9126-9130 . \\
\text { Telling et al. } 1996 \text { Genes Dev 10: } 1736-1750 .\end{array}$ \\
\hline & MoPrP(3F4)-PG14 & Familial;Octarepeat & 28 copies & 4 -fold & prion disease & ${ }^{5}$ Accelerated & $100-200$ days & ${ }^{3} \mathrm{PrPS}$-like & no & N.S. & Chiesa et al. 1998 Neuron 21: 1339-1351. \\
\hline & MoPrP-D177N/L108M/V111M & Familial: CJD(FFI)D178N & 2 copies (knock-in) & N.D. & & prion disease & 16 months & Yes & Yes & N.S. & Jackson et al. 2009 Neuron 63: 438-450. \\
\hline & MoPrP-D177N/V128 & Familial CJD(FFI)D178NV129 & 22 copies & 1 -fold & ${ }^{5}$ Accelerated & prion disease & 72 days & Yes & N.S. & N.S. & Dossena et al. 2008 Neuron $60: 598-609$. \\
\hline & MoPrP-A116V/V128 & Famillial; GSSA117V & N.S. & 6 -fold & & Neurodegeneration & $140-170$ days & Yes & N.S. & $\mathrm{C} 1$ & Yang et al. 2009 J Neuroscience 29: 10072. \\
\hline & $\operatorname{MoPrP}(\triangle \mathrm{GPI})$ & Famillial; GSS & N.S. & 1.7 -fold & ${ }^{5}$ Accelerated & prion disease & 597 days & Yes & Yes & N.S. & Stohr et al. 2011 PNAS 108: 21223-21228. \\
\hline \multirow{9}{*}{${ }^{2} \Delta \mathrm{F}$-type } & MoPrP- $\Delta F(\Delta 32-134)$ & Artificial & 20 copies & 2 -fold & ${ }^{5}$ rescued & Neurodegeneration & $30-90$ days & no & no & ${ }^{4} \mathrm{no} \mathrm{C} 1$ & Shmerling et al. 1998 Cell 93: 203-214. \\
\hline & MoPrP- $\Delta \operatorname{CD}(\Delta 94-134)$ & Artificial & $1-5$ copies & 0.8 -fold & ${ }^{5}$ rescued & Neurodegeneration & $10-25$ days & no & no & ${ }^{4}$ no $\mathrm{Cl}$ & Baumann et al. 2007 EMBO J 26:538-547. \\
\hline & $\operatorname{MoPrP}-\triangle \mathrm{pHC}(\Delta 114-121)$ & Artificial & $1-5$ copies & 0.8 -fold & & normal & & no & no & reduced C1 & Baumann et al. 2007 EMBO J 26-538-547. \\
\hline & $\operatorname{MoPrP}-\Delta \mathrm{CC}(\Delta 94-110)$ & Artificial & N.S. & N.S. & N.S. & normal & no & no & no & reduced C1 & Bremer et al. 2010 Nat Neurosci 13: 310-320. \\
\hline & $\operatorname{MoPrP}-\Delta \mathrm{CR}(\Delta 105-125)$ & Artificial & N.S. & 1 -fold & ${ }^{5}$ rescued & Neurodegeneration & 6 days & no & no & ${ }^{4}$ no $\mathrm{Cl}$ & Li et al. 2007 EMBO J 26: 548-558. \\
\hline & Mo-CD_Dpl(PrP90-133eDpl65-66) & Artificial & 126 copies & 1 -fold & N.S. & normal & & no & no & & Baumann et al. 2009 PLoS One 4: e6707. \\
\hline & Mo-PrP_Dpl(PrP1-133@Dpl66) & Artificial & $180-120$ copies & 0.4 -fold & N.S. & normal & no & no & no & ${ }^{4}$ no $\mathrm{C} 1$ & Baumann et al. 2009 PLoS One 4: e6707. \\
\hline & MoPrP- $\triangle 23-134 a$ & Artificial & N.S. & 2 -fold & N.S. & normal & no & no & no & & Westergard et al. $2011 \mathrm{~J}$ Neuroscience 28: 14005-1401 \\
\hline & MoPrP-Tg(C1) $(\Delta 23-111)$ & Artificial & N.S. & 7-fold & N.S. & normal & no & no & no & & Westergard et al. 2011 JBC 286: 44234-44242. \\
\hline \multirow{12}{*}{ Others } & Sha-T183A/T199A & Aritificial & N.S. & 4 4-fold & 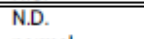 & normal & no & no & 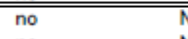 & $\begin{array}{l}\text { N.S. } \\
\text {. }\end{array}$ & DeArmond et al. 1997 Neuron 19: 1337-1348. \\
\hline & MoPrP-P101L & Familial; GSSP102L & 2 copies (knock-in) & N.D. & normal & normal & no & no & no & N.S. & Manson et al. 1999 EMBO 18: 6855-6864. \\
\hline & MoPrP-L9R/3AV(A1 12A114A117 $\rightarrow$ I & Artificial & N.S. & 0.5 -fold & ${ }^{5}$ Accelerated & Neurodegeneration & $21-389$ days & no & no & N.S. & Stewart et al. $2005 \mathrm{~J}$ Neuroscience 25: 3469-3477. \\
\hline & MHM2-( $(\Delta 23-88 \& \Delta 177-200)$ & Artificial & N.S. & 0.5 -fold & N.S. & Neurodegeneration & $46-227$ days & ${ }^{3}$ PrPSc-like & N.S. & N.S. & Muramoto et al. 1997 Nature Med. 3: 750-755. \\
\hline & MHM2-( $(\Delta 23-88 \& \Delta 201-217)$ & Artificial & N.S. & 2 -fold & N.S. & Neurodegeneration & $67-165$ days & ${ }^{3} \mathrm{PrPS}_{\mathrm{c}}-\mathrm{like}$ & N.S. & N.S. & Muramoto et al. 1997 Nature Med 3: 750-755. \\
\hline & MoPrP-E199K & Familial: CJDE200K & N.S. & 8 -fold & normal & N.S. & & no & no & N.S. & Telling et al. 1996 Genes Dev $10: 1736-1750$. \\
\hline & MH2M-AV3(A113A115A118 $\rightarrow$ V) & Artificial & N.S. & 4 -fold & N.D. & Neurodegeneration & 60 days & no & N.D. & N.S. & Hegde et al. 1998 Science 279:827-834. \\
\hline & Sha-A117V & Famillial; GSSA117V & N.S. & 4 -fold & N.D. & Neurodegeneration & 572 days & no & no & N.S. & Hegde et al. 1999 Nature $402: 822-826$. \\
\hline & Sha-N108I & Famillial; CJDN108I & N.S. & 4 -fold & N.D. & Neurodegeneration & 312 days & no & no & N.S. & Hegde et al. 1999 Nature $402: 822-826$. \\
\hline & Sha-KH $\rightarrow \mathbb{I}$ & Artificial & N.S. & 4-fold & N.D. & Neurodegeneration & 58 days & no & no & N.S. & Hegde et al. 1998 Science 279:827-834. \\
\hline & Sha- $\triangle \operatorname{STE}(\Delta 104-113)$ & Artificial & N.S. & 4-fold & N.S. & normal & & & no & N.S. & $\begin{array}{l}\text { Hegde et al. } 1999 \text { Nature } 402: 822-826 \text {. } \\
\text { Hegde et al. } 1999 \text { Nature } 402: 822-826 \text {. }\end{array}$ \\
\hline & 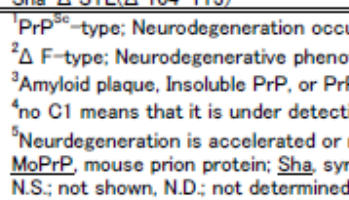 & $\begin{array}{l}\text { otypes are rescued by the introd } \\
\text { rP deposition are seen in the ill } n \\
\text { tion level by westem blot analysi } \\
\text { resuced in the presence or abs } \\
\text { rrian hamster prion protein; } \text { MHM }\end{array}$ & $\begin{array}{l}\text { is. } \\
\text { sence of } \mathrm{PrP} \\
\text { C. }\end{array}$ & $\begin{array}{lll} & 0\end{array}$ & Nue it. & & 型 & 列 & 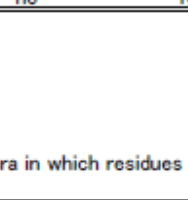 & 型 & 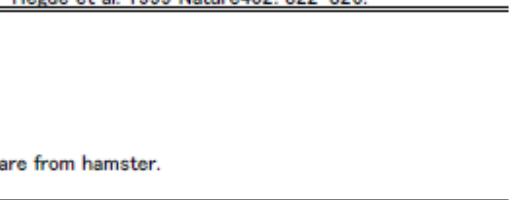 \\
\hline
\end{tabular}


Aguzzi's group developed transgenic mice, expressing PrP variants lacking residues 94$134(\triangle \mathrm{CD})$ or 114-121( $\triangle \mathrm{pHC}$ ) (Figure 2) [33]. These deletion mutants are quite interesting because $94-$ 134 encompasses the $\mathrm{CC}, \alpha$-cleavage and $\mathrm{HC}$ sites, and 114-121 includes the $\mathrm{N}$-terminal palindrome sequence (AGAAAAGA), which is highly conserved among species and is thought to be important for the conversion into $\operatorname{PrP}^{\mathrm{Sc}}[34,35]$. These transgenic mice showed distinct phenotypes on a Prnp ${ }^{0 / 0}$ background. $\triangle \mathrm{CD}$ (94-134) mice spontaneously developed neurodegenerative diseases, while $\Delta \mathrm{pHC}$ (114-121) mice did not [33]. The striking difference compared to $\Delta \mathrm{F}$ (32-134) mice is that $\Delta \mathrm{CD}$ (94134) mice show more severe neurodegeneration, since the phenotypes were observed even on a Prnp ${ }^{+/+}$ background. To overcome the neurotoxicity caused by $\triangle \mathrm{CD}$ (94-134), either low expression of the exogenous $\triangle \mathrm{CD}$ (94-134) or the introduction of exogenous high $\operatorname{PrP}^{\mathrm{C}}$ expression, such as in Tga20 mice, are required [33]. Upon PNGase-F treatment of the brain homogenates from those mice, $\operatorname{PrP}^{\mathrm{C}}$ displayed a significant amount of $\mathrm{C} 1$, whereas $\mathrm{C} 1$ formation was reduced in $\triangle \mathrm{pHC}(114-121)$ and absent from $\triangle \mathrm{CD}$ (94-134) [33], supporting the model dictating that blockade of $\alpha$-cleavage of $\operatorname{PrP}^{\mathrm{C}}$ makes it toxic. Similar results were also obtained in $\mathrm{Tg}(\Delta \mathrm{CR})$ mice by Harris's group where $\operatorname{PrP}^{\mathrm{C}}$ was deleted between residues 105 and 125, which include the $C C$ and $\mathrm{HC}$ regions (105-125). This deletion appears to be the minimum mutation required to block $\alpha$-cleavage of $\operatorname{PrP}^{\mathrm{C}}$ in vivo using transgenic mice. Interestingly, accumulating results have shown that PrP peptide 106-126 is highly toxic in both murine and human neurons. However, further investigation is required to clarify the relation between $\operatorname{PrP} 106-126$ and $\alpha$-cleavage phenomenon. The same group also showed that $\Delta C R(105-125)$ is expressed on the surface of neurons, but $\mathrm{C} 1$ generation is undetectable by western blot analysis of brain homogenate (Figure 2) [36].

All of the above mice had spontaneous neurodegenerative dysfunction and importantly the dysfunction can be rescued by normal $\mathrm{PrP}^{\mathrm{C}}$ in a dose dependent manner of $\operatorname{PrP}^{\mathrm{C}}$ expression. In contrast, other transgenic mice including MoPrP-P101L, MoPrP-PG14, MoPrP-D177N and MoPrPA116V showed spontaneous neurodegeneration, but the phenotypes were not rescued by $\operatorname{PrP}^{\mathrm{C}}$ expression, which instead exacerbated the phenotypes (Table 1) [27,28,29,37,38,39,40,41]. Most strikingly, these mice appear to spontaneously generate $\mathrm{PrP}^{\mathrm{Sc}}$ or amyloid plaque. In addition, their disease is often transmissible if "species barrier" is considered. Thus, these transgenic mice are likely a valuable model for prion disease. Although the generation of $\mathrm{C} 1$ was not assessed in these mice, $\alpha$ cleavage of these mutant PrPs would occur fully or partially, since an in vitro system by OliveiraMartins et al. showed that $\alpha$-cleavage is unexpectedly tolerant to mutations unless a large portion of $\mathrm{PrP}^{\mathrm{C}}$ is deleted [30]. However, it still remains to be determined how " $\mathrm{PrP}^{\mathrm{Sc}}$-type" could be explained by the " $\alpha$-cleavage phenomenon".

In 1995 Gambetti's group described that an additional fragment longer than $\mathrm{C} 1$, designated $\mathrm{C} 2$, is present in substantial amounts in CJD brains, but not in normal controls [21]. Thus, $\mathrm{C} 1$ and $\mathrm{C} 2$ seem to be completely different in terms of physiological function, because $\mathrm{C} 2$ appears to be pathogenic. Interestingly, $\mathrm{C} 2$ seems to have the $3 \mathrm{~F} 4$ epitope, meaning that $\mathrm{C} 2$ contains at least the residues between 90 and 104, which is upstream of the $\alpha$-cleavage site (110 or 111). Thus, C2 is the fragment of $\operatorname{PrP}^{\mathrm{C}}$ that was not cleaved at the $\alpha$-cleavage site.

In 2006, Telling's group produced transgenic mice, expressing GFP-tagged murine PrP at codon 22 [42]. In addition to the study of the GFP-PrP $\mathrm{P}^{\mathrm{C}}$, they tested a murine adopted scrapie (RML) infection. Interestingly, they used both PNGase $\mathrm{F}$ and Proteinase $\mathrm{K}$ to detect $\mathrm{PrP}^{\mathrm{Sc}}$. Normal mice showed two 
bands on $\mathrm{WB}, \operatorname{PrP}^{\mathrm{C}}$ and $\mathrm{C} 1$, and both bands were completely digested by Proteinase $\mathrm{K}$ treatment at 20 $\mu \mathrm{g} / \mathrm{ml}$. On the other hand, normal mice infected with RML showed three bands, $\operatorname{PrP}^{\mathrm{C}}, \mathrm{C} 1$ and $\mathrm{C} 2$. The data demonstrates that after Proteinase $\mathrm{K}$ treatment at $20 \mu \mathrm{g} / \mathrm{mL} \mathrm{C} 2$ is retained, but not $\operatorname{PrP}^{\mathrm{C}}$ and $\mathrm{C} 1$, suggesting that $\mathrm{C} 2$ is the $\operatorname{PrP}^{\mathrm{Sc}}[43]$.

As previously described, Prusiner's group produced Tg mice overexpressing MoPrP-P101L, which spontaneously developed central nervous system dysfunction and transmissible, even though Proteinase K resistant $\mathrm{PrP}^{\mathrm{Sc}}$ was not detected. In 2005, Telling's group revisited this issue [44]. They used the cold PK technique (Proteinase $\mathrm{K}$ treatment on ice), PNGase F, and $\mathrm{PrP}^{\mathrm{Sc}}$-specific antibody (15B3) to show the appearance of a proteinase resistant form of MoPrP-P101L with molecular weights corresponding to $\mathrm{C} 2$. Thus, $\mathrm{PNGase} \mathrm{F}$ can be a powerful tool to detect proteinase $\mathrm{K}$ sensitive $\mathrm{PrP}^{\mathrm{Sc}}$, because contrary to Proteinase $\mathrm{K}$ treatment, which can completely digest the target protein depending on incubation time and concentration, the experimental impact of varying PNGase $F$ treatment conditions is minimal. It will be interesting to test for the presence of such $\mathrm{PrP}^{\mathrm{Sc}}$ using a similar technique in the MoPrP-PG14, MoPrP-D177N, and MoPrP-A116V transgenic mice.

In 1998, Lingappa's group reported transgenic mice expressing several mutant PrP, including $\Delta$ STE(104-113), G123P, $\mathrm{KH} \rightarrow \mathrm{II}(\mathrm{K} 110 \mathrm{H} 111$ to I110I111 substitutions), AV3(V113V115V118 to A113A115A118 substitutions), A117V (human GSS) and N108I (human CJD) on hamster $\operatorname{PrP}^{\mathrm{C}}$ $[45,46]$. Among these mice, $\mathrm{KH} \rightarrow \mathrm{II}, \mathrm{A} 117 \mathrm{~V}, \mathrm{AV} 3$, and N108I PrP expression induced spontaneous neurodegeneration, but importantly, $\operatorname{PrP}^{\mathrm{Sc}}$ was not detected in these mice. Previously, the same group studied PrP translocation at the endoplasmic reticular (ER) membrane and revealed unusual features in its biogenesis. They found more than one topologic form of full-length $\operatorname{PrP}^{\mathrm{C}}$ synthesized in cell-free translation systems, including at least secPrP, NtmPrP, and $\mathrm{CtmPrP}$ [45]. Interestingly, they also showed that favored synthesis in the $\mathrm{CtmPrP}$ form strongly correlates with neurodegenerative phenotypes such that mice expressing $\mathrm{KH} \rightarrow \mathrm{II}$ (toxic), A117V (toxic), and AV3 (toxic) have relatively more $\mathrm{CtmPrP}$ in their brains. They concluded that expression of $\mathrm{CtmPrP}$ produces neurodegenerative changes. It remains to be determined whether the neurodegenerative phenotypes by $\mathrm{KH} \rightarrow \mathrm{II}, \mathrm{A} 117 \mathrm{~V}$, and AV3 mice are rescued by $\operatorname{PrP}^{\mathrm{C}}$ or whether $\mathrm{C} 1$ is generated in these mice.

Mice expressing the " $\Delta \mathrm{F}$ type" PrP have so far not been shown to generate a relevant $\mathrm{C} 2$ fragment. On the contrary, it is possible that all mice with the "PrP ${ }^{\mathrm{Sc}}$ type" may show a prominent $\mathrm{C} 2$. The finding that $\operatorname{PrP}^{\mathrm{Sc}}$ might be the $\mathrm{C} 2$ is interesting, because $\operatorname{PrP}^{\mathrm{Sc}}$ is not cleaved at the $\alpha$-cleavage site. Therefore, expression of "PrP ${ }^{\mathrm{Sc}}$ type" mutants would also affect $\alpha$-cleavage because certain mutations of $\operatorname{PrP}^{\mathrm{C}}$ result in the generation of $\operatorname{PrP}^{\mathrm{Sc}}$ that is resistant to $\alpha$-cleavage or $\operatorname{PrP}^{\mathrm{Sc}}$ that blocks $\alpha$-cleavage of $\operatorname{PrP}^{\mathrm{C}}$ through interactions with each other (see Figure 3). 
Figure 3. (A) When $\operatorname{PrP}^{\mathrm{C}}$ is not cleaved by deletion or mutation, the PrPs elicit neurotoxicity. (B) When the $\alpha$-cleavage of $\operatorname{PrP}^{\mathrm{C}}$ is blocked, the unstable PrPs tend to spontaneously aggregate to generate $\operatorname{PrP}^{\mathrm{Sc}}$. The generated $\operatorname{PrP}^{\mathrm{Sc}}$ then affect the $\alpha$-cleavage of neighboring $\operatorname{PrP}^{\mathrm{C}}$ to elicit neurotoxicity or the conversion process from $\operatorname{PrP}^{\mathrm{C}}$ to $\operatorname{PrP}^{\mathrm{Sc}}$ by itself transduces a toxic signal. A mutation or deletion may occur on single allele or in single cell.

A. SF-type diseases (one step)

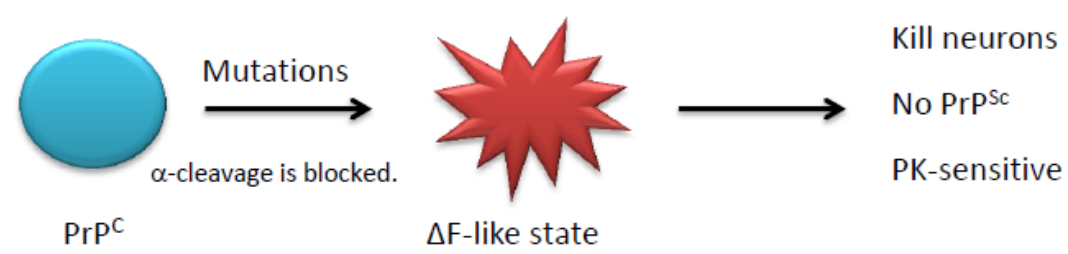

B. PrPsc-type diseases (two steps)

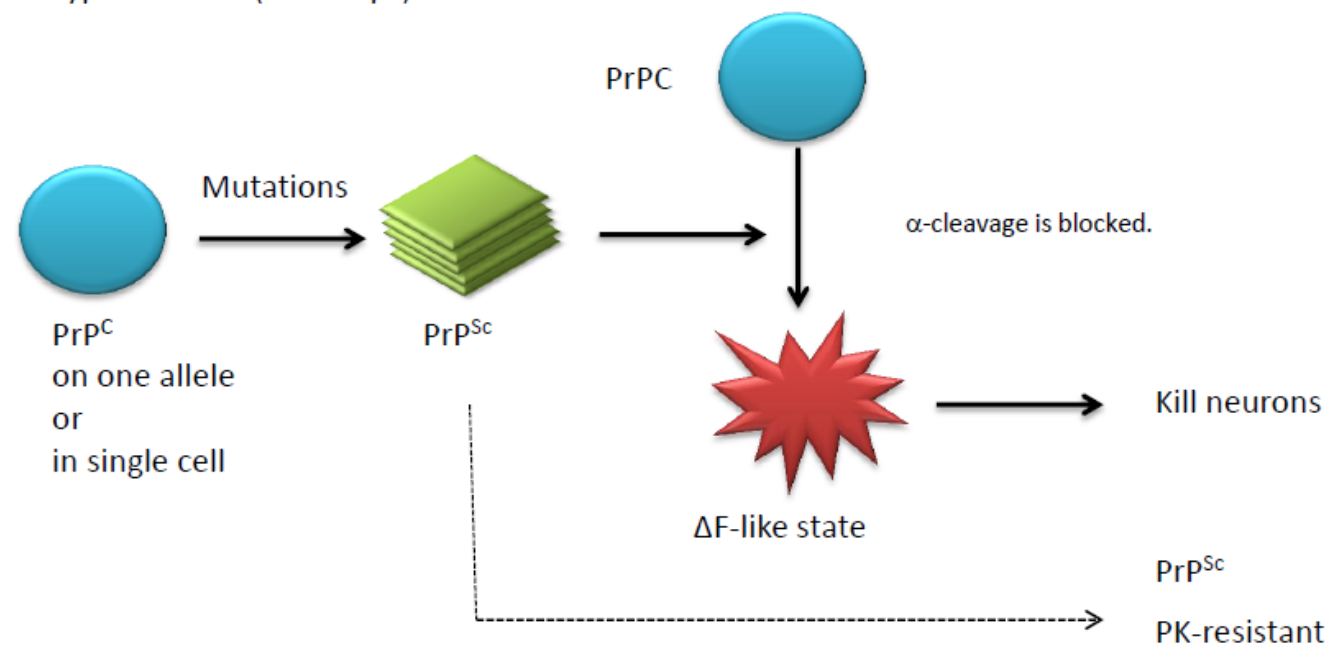

Is the reduction of $\mathrm{C} 1$ or inefficient $\alpha$-cleavage of $\operatorname{PrP}$ toxic? One hint to answer this question can be deduced from the experiments performed by Aguzzi's group [33]. As discussed above, C1 formation was reduced in mice expressing $\triangle \mathrm{pHC}(114-121)$ and absent from when $\triangle \mathrm{CD}(32-134)$ is expressed (Figure 2). It might be possible that the presence of $\Delta \mathrm{pHC}$ still retains un-cut $\mathrm{PrP}^{\mathrm{C}}$, which was supposed to be cleaved at the correct position and time. Therefore, presence of $\Delta \mathrm{pHC}$ may retain some residual toxicity, which cannot be observed in the short life span of a mouse. Accordingly, the introduction of $\triangle \mathrm{pHC}$ into $\triangle \mathrm{CD}$ mice enhanced the phenotypes [33], suggesting that $\Delta \mathrm{pHC}$ induces residual toxicity. In addition, the introduction of $\Delta \mathrm{pHC}$ into $\Delta \mathrm{F}$ mice partially rescued the $\Delta \mathrm{F}$ phenotypes [33], indicating that $\Delta \mathrm{pHC}$ also retains a function of $\operatorname{PrP}^{\mathrm{C}}$, since it is partially cleaved. These findings support a mechanistic model that cleaved and un-cleavable PrPs exist simultaneously with $\triangle \mathrm{pHC}$; one is non-toxic and able to rescue $\Delta \mathrm{F}$ phenotypes and the other is toxic and enhances $\Delta \mathrm{CD}$ neurotoxicity (Figure 4C). 
Figure 4. (A) Full-length $\operatorname{PrP}^{\mathrm{C}}$ has a function so that it is immediately cleaved at $\alpha$ cleavage site after activation. (B) Either N1 or C1 is an active form so that it is cleaved at $\alpha$-cleavage site to activate it. $(C) \operatorname{PrP}^{\mathrm{C}}$ with mutations is not completely cleaved so that the uncleavable PrP show some residual toxicity. (D) Spontaneously generated $\mathrm{PrP}^{\mathrm{Sc}}$ on one gene or derived from single cell blocks the $\alpha$-cleavage of the remaining $\operatorname{PrP}^{\mathrm{C}}$, resulting in neurodegeneration. Infectious Prions also blocks the $\alpha$-cleavage of host $\operatorname{PrP}^{\mathrm{C}}$.
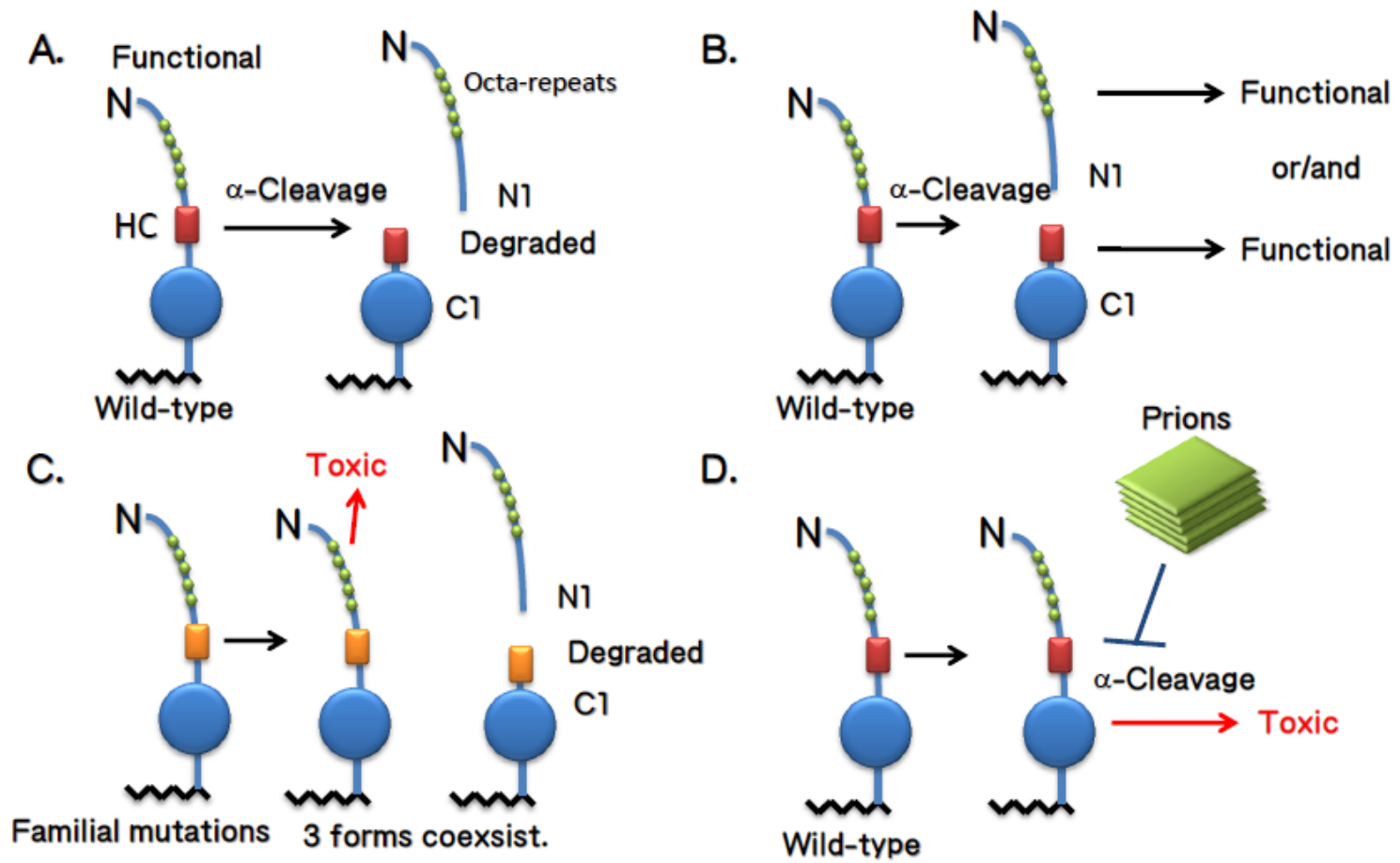

What is the nature of neurotoxicity caused by expression of PrPs of the " $\Delta \mathrm{F}$ type"? Although the endogenous physiological $\mathrm{C} 1$ does not contain residues 1 to 110 or 111 , Harris's group pointed out that the artificial PrP constructs, such as $\Delta 32-134, \Delta 94-134$, and $\Delta 105-125$, retain the N-terminal 9 amino acids (residues 23-31, KKRPKPGGW) (Figure 2). Therefore, they engineered transgenic mice expressing a PrP mutant with 23-134 deleted ( $\Delta 23-134)$ [47]. According to their report, these mice surprisingly did not display clinical symptoms or neuropathology, in contrast to mice expressing $\Delta 32$ 134, $\Delta 94-134$, or $\Delta 105-125$ [26,33,48]. Importantly, $\Delta 23-134$ (non-toxic), $\Delta 32-134$ (toxic), $\Delta 94-$ 134(toxic), and $\Delta 105-125$ (toxic) PrPs are expressed on the surface of cells, but did not seem to be cleaved to generate $\mathrm{C} 1$, thereby rejecting the notion that the blockade of $\alpha$-cleavage correlates with neurotoxicity by PrP mutants. In addition, neither $\Delta 23-134$ (non-toxic) nor $\Delta 32-134$ (toxic) PrPs were efficiently endocytosed, while $\Delta 105-125$ (toxic) PrP was efficiently endocytosed in an in vitro cell culture system, indicating that the lack of toxicity of the $\Delta 23-134$ mutant cannot be attributed to its impaired endocytosis. This report suggests that the toxicity caused by PrP mutants that cannot generate C1 relates to presence of the nine amino acids (KKRPKPGGW). Similar evidence was previously shown by Prusiner's group, where a $\Delta 23-88$ mutant PrP was introduced into Prnp-deficient mice [49]. Their transgenic mice seemed to be normal, but the 23-88 mutant $\operatorname{PrP}$ does not seem to be functional, because it failed to rescue the mice from the Purkinje cell death in Ngsk Prnp ${ }^{0 / 0}$ mice [50]. Thus, both $\Delta$ 23-134 (un-cleavable) and $\Delta 23-88$ (cleavable) mutant PrPs might be non-functional. 
As discussed in the Introduction, both function and toxicity require prion protein localization at the plasma membrane. Consistent with this requirement, PrP $\Delta$ CDs lacking residues 94-134 or the GPIanchor were shown to be non-toxic [33]. In addition, expression of GPI-anchorless PrP did not rescue Mo-PrP $\Delta \mathrm{F}(\Delta 23-134)$, although it did show partial residual rescue [51]. Recently, Prusiner's group produced $\operatorname{Tg}(\operatorname{PrP}, \Delta \mathrm{GPI})$-expressing mice on a $\operatorname{Prnp}^{0 / 0}$ background [52]. Mice engineered with low expression of the exogenous $\Delta \mathrm{GPI}$ mutant remained healthy, as previously reported [12]. In contrast, 1.7-fold higher expression of the $\Delta$ GPI mutant compared with $\operatorname{PrP}^{\mathrm{C}}$ expression levels of wild-type mice resulted in late-onset, spontaneous neurologic illness accompanied by amyloid plaques. In addition, the disease was transmissible. Thus, $\operatorname{Tg}(\operatorname{PrP}, \Delta \mathrm{GPI})$ mice can be categorized into the " $\operatorname{PrP} \mathrm{P}^{\mathrm{Sc}}$ type". Because anchorless PrPs are not cleaved, it might be possible that the un-cut $\operatorname{PrP}$ tends to spontaneously aggregate (Figure 3B).

In conclusion, there have been at least two major types of transgenic mouse models produced to date. The first type directly produce $\operatorname{PrP}^{\mathrm{Sc}}$ derived from exogenous mutant $\operatorname{PrP}$ transgenes so that the mice suffer from prion disease and the disease can be transmissible to other mice. Thus, endogenous $\mathrm{PrP}^{\mathrm{C}}$ expression rather enhances the disease in these mice. The second type has nothing to do with prion disease in terms of $\mathrm{PrP}^{\mathrm{Sc}}$ and transmissibility. These mice show neurodegenerative phenotypes in the absence of $\operatorname{PrP}^{\mathrm{C}}$. Thus, the introduction of $\operatorname{PrP}^{\mathrm{C}}$ rescues the phenotypes of these mice. In these mice, the exogenous artificial $\operatorname{PrP}$ mutants are extremely resistant to " $\alpha$-cleavage", while $\operatorname{PrP}^{\mathrm{C}}$ is mainly cut into two fragments, $\mathrm{N} 1$ and $\mathrm{C} 1$.

How could the divergent phenotypes of these two mouse models be explained by a unified hypothesis? One hypothetical model to explain this dichotomy is illustrated in Figure 3. We propose that when $\operatorname{PrP}^{C}$ is not cleaved at all by deletion or mutation, the PrPs elicit neurotoxicity ( $\Delta \mathrm{F}$ type) or the $\operatorname{PrPs}$ spontaneously aggregate to generate $\operatorname{PrP}^{\mathrm{Sc}}$ ( $\operatorname{PrP}^{\mathrm{Sc}}$ type), depending upon the mutations involved. When $\operatorname{PrP}^{\mathrm{C}}$ is partially cleaved by mutation, three forms should exist simultaneously: un-cut PrP, N1, and C1 (i.e. $\triangle \mathrm{pHC}$ ). Thus, un-cut PrP may induce mild neurotoxicity that cannot be observed under normal conditions. We further propose that neurotoxicity by the un-cut PrP is evident in the presence of other mutant PrPs, since double transgenic mice with $\triangle \mathrm{pHC}$ (non-toxic) and $\Delta \mathrm{CD}$ (toxic) enhanced the neurodegenerative phenotypes of $\Delta \mathrm{CD}$ mice [33]. On the other hand, expression of $\Delta \mathrm{pHC}$ can partially rescue the neurotoxicity induced by $\Delta \mathrm{F}$ (toxic). It might be possible that $\mathrm{N} 1$ or $\mathrm{C} 1$ derived from $\triangle \mathrm{pHC}$ rescues the neurotoxicity induced by $\Delta \mathrm{F}$. Furthermore, we predict that $\Delta \mathrm{CD}$ expression cannot be rescued by $\Delta \mathrm{pHC}$ because $\Delta \mathrm{CD}$ possesses a long $\mathrm{N}$-terminal domain, which might block the functions of N1, C1, or full-length $\operatorname{PrP}^{\mathrm{C}}$.

\section{Doppel and Shadoo}

\subsection{Doppel}

In order to address the function of $\operatorname{PrP}^{\mathrm{C}}$, several $\operatorname{PrP}^{\mathrm{C}}$-deficient mouse lines were developed by many laboratories, including Zrch I, Rcm0, Npu/Edbg, Ngsk, Rikn, and Zrch II [8,53,54,55,56,57,58]. Zrch I and Npu mice developed and reproduced normally, while Rcm0, Ngsk, Rikn and Zrch II mice exhibited severe ataxia and Purkinje cell loss in later life, as well as demyelination of peripheral nerves. Spontaneous cerebellar neurodegeneration seen in these mice led to the discovery of doppel 
(Dpl), a protein structurally related to $\operatorname{PrP}^{\mathrm{C}}$ [54]. The mouse gene Prnd (Dpl) is located 16 kilobases downstream of Prnp $\left(\operatorname{PrP}^{\mathrm{C}}\right)$ and encodes a 179-amino acid protein. Dpl is absent from the brain and is highly expressed in testis under normal physiological condition. In accordance with its expression, Dpl-deficient mice showed a male infertility phenotype [59,60]. The deletions designed in Rcm0, Ngsk, and Zrch II mutants resulted in the generation of high levels of Dpl expression in the brain by an unusual mechanism involving exon-skipping and intergenic splicing. Interestingly, the introduction of a single wild-type PrP allele fully rescued the deleterious phenotype caused by the ectopic expression of Dpl in the brain [58], indicating that Dpl has a functional overlap with $\operatorname{PrP}^{\mathrm{C}}$. Dpl shows structural homology with the $\mathrm{C}$-terminal globular domain of $\operatorname{PrP}^{\mathrm{C}}$, but lacks the $\mathrm{N}$-terminal octarepeats and the hydrophobic core (HC) [61], suggesting that $\mathrm{Dpl}$ is not cleaved at the same position as $\operatorname{PrP}^{\mathrm{C}}$. As expected, murine Dpl appears as a single band of $\sim 17 \mathrm{KDa}$ after PNGase F treatment [62], although human Dpl from testis additionally possesses an O-bound oligosaccharide [63,64]. Interestingly, Aguzzi's group produced mice expressing fusion proteins in which the $\mathrm{CC}$ and $\mathrm{HC}$ regions of $\operatorname{PrP}^{\mathrm{C}}$ (residues 90-133) (cleavable) were inserted into the middle of Dpl (between 65 and 66), and the chimeric CD-Dpl proteins are cleaved into two fragments [65]. These mice did not show the neurodegeneration phenotype seen by ectopic Dpl expression in several $\operatorname{PrP}^{\mathrm{C}}$-deficient mice (i.e. Rcm0, Ngsk, Rikn and Zrch II), although these fusion proteins are artificial so their functional integrity is unclear. However, the CD-Dpl expression in either PrP- $\Delta \mathrm{F}(\Delta 32-134)$ or PrP- $\Delta \mathrm{CD}(\Delta 94-134)$ mice partially rescued the severe neurodegeneration caused by expression $\Delta \mathrm{F}$ or $\Delta \mathrm{CD}$ [65], indicating that the CD-Dpl proteins are at least partially functional. The same group also produced mice expressing the PrP-Dpl proteins in which the N-terminal domain of PrP (1-133) is fused to the C-terminal domain of Dpl (66-179). These PrP-Dpl fusion proteins are not toxic in the $\mathrm{PrP}^{\mathrm{C}}$-deficient mice, even in the absence of C1-like molecules as shown by western blot analysis, implying no correlation between toxicity and lack of $\mathrm{C} 1$. It is possible that the PrP-Dpl fusion did not cause neurodegeneration because it is non-functional, but this does not seem to be the case as it partially, albeit weakly, rescued the $\Delta \mathrm{F}$ and $\triangle \mathrm{CD}$ phenotypes [65]. One possible explanation for the rescue of the $\Delta \mathrm{F}$ and $\Delta \mathrm{CD}$ phenotypes by PrP-Dpl is that the fusion protein still retains capacity to generate a residual level of $\mathrm{C} 1$ fragment that is below detection level by normal western blot analysis, since weak $\mathrm{C} 1$ expression was shown to partially rescue the $\Delta \mathrm{F}$ phenotypes in $\Delta \mathrm{pHC}$ and $\Delta \mathrm{F}$ double transgenic mice [33]. In addition to the $\alpha$ cleavage phenomenon, one could conclude from these studies that the N-terminal 9 amino acids (2331 ) and residues 90 to 133, which include the $\mathrm{CC}, \alpha$-cleavage site, and $\mathrm{HC}$ domains, but not the octarepeats, are sufficient to rescue the toxicity caused by $\Delta \mathrm{F}, \Delta \mathrm{CD}$, and Dpl.

\subsection{Shadoo}

Database analysis by Gready's group identified a novel gene named SPRN (Shadoo), shadow of prion protein (Sho) [66]. Dpl resembles the $\alpha$-helical C-terminal half of $\operatorname{PrP}^{\mathrm{C}}$, while Sho is reminiscent of the flexible N-terminal half, although Sho is extracellular and GPI-anchored. The SPRN gene was also found in zebrafish, Fugu, rat, mouse, cow and human [67] and was shown to have an overlapping pattern of expression in the central nervous system, similar to that of $\operatorname{PrP}^{\mathrm{C}}[68,69]$. In particular, the similarity between PrP and Sho is striking within the putative HC region, suggesting that Sho, but not Dpl, undergoes $\alpha$-cleavage. 
As anticipated, Westaway's group have shown that Sho is indeed cleaved at the putative $\alpha$-cleavage site [68], although the sequence of the Sho-C1 has not yet been determined to identify the exact cleavage site. If Sho is cleaved to generate a "C1-like molecule", it would be interesting to test whether expression of an "un-cleavable Sho" mutant can cause neuronal cell death like expression of the $\Delta \mathrm{F}$ PrP mutant in the absence of wild-type Sho or $\operatorname{PrP}^{\mathrm{C}}$. Obviously, Sho does not seem to compensate for the lack of $\operatorname{PrP}^{\mathrm{C}}$, since ectopic expression of Dpl causes neuronal dysfunction in the absence of $\operatorname{PrP}^{\mathrm{C}}$, but Sho should still be present, although Sho expression was not tested in the Rcm0, Ngsk, and Zrch II mice.

Collectively, the mammalian prion protein family consists of three members: ubiquitously expressed $\mathrm{PrP}^{\mathrm{C}}$, testis-localized (although not exclusively) Dpl, and neuron-localized (although not exclusively) Sho. Since $\mathrm{PrP}^{\mathrm{C}}$ null mice develop normally and are completely resistant to prion infections, another molecule has been suggested to compensate the function of $\operatorname{PrP}^{\mathrm{C}}$. Sho is a good candidate for such compensation, but this does not seem to be the case. A recent publication by Westaway's group has reported the analysis of mice deficient in both Sho and $\operatorname{PrP}^{\mathrm{C}}$, and these mice were fertile and viable for up to 690 days of age [70]. These results directly contradict the hypothetical redundancy between $\mathrm{PrP}^{\mathrm{C}}$ and Sho. In sharp contrast, however, Laude and Vilotte's group [69] previously reported that Sprn knockdown in $\operatorname{PrP}^{\mathrm{C}}$ deficient embryos using a lentiviral system resulted in embryonic lethality. The explanation for this discrepancy needs further investigation, but may be due to the different experimental strategies used.

\section{The cellular compartment in which $\alpha$-cleavage occurs}

Prion infection into animals and humans results in the conversion of $\operatorname{PrP}^{\mathrm{C}}$ into scrapie prion protein $\left(\mathrm{PrP}^{\mathrm{Sc}}\right)$ [71]. The conversion of $\operatorname{PrP}^{\mathrm{C}}$ to $\mathrm{PrP}^{\mathrm{Sc}}$ is clearly a posttranslational process [14]. One study proposed that the conversion process occurs intracellularly between the Golgi and the cell surface, since $\operatorname{PrP}^{\mathrm{Sc}}$ was not released by phosphatidylinositol-specific phospholipase C (PIPLC) in the scrapieinfected murine neuroblastoma cell line, $\mathrm{N} 2 \mathrm{a}$ [72]. In support of this mechanism, $\mathrm{PrP}^{\mathrm{Sc}}$ was shown to be co-localized with the Golgi marker in murine N2a and Syrian hamster-derived HaB cells [73]. In contrast, Caughey's group reported in 1991 that the precursor of $\operatorname{PrP}^{\mathrm{Sc}}$ was eliminated from intact cells by treatments with PIPLC and trypsin, suggesting that the conversion of $\operatorname{PrP}^{\mathrm{C}}$ to $\operatorname{PrP}^{\mathrm{Sc}}$ occurs after the precursor reaches the cell surface in rat PC12 cells [74]. Collectively, it seems that the conversion occurs between the cell surface and the Golgi compartment and further study is warranted.

$\mathrm{N} 2 \mathrm{a}$ is the most frequently and broadly used cell model for in vitro study of prion infection, although it is derived from murine cells, thereby limiting its use [75]. Many laboratories have reproducibly demonstrated prion infection into N2a cells, presumably due to a unique cellular attribute. The mechanism of $\operatorname{PrP}^{\mathrm{C}}$ endocytosis has been studied frequently using N2a cells [76]. In 1993, Harris's group used $\mathrm{N} 2 \mathrm{a}$ cells to demonstrate that $\operatorname{PrP}^{\mathrm{C}}$ cycles between the cell surface and an endocytic compartment [77]. In 2004, Kaneko's group expressed fusion proteins of PrP with either EGFP or DsRed in N2a cells to show that both endogenous $\mathrm{PrP}^{\mathrm{C}}$ and the fluorescent fusion proteins are localized at both the cell surface and the perinuclear compartment (PNC), part of which seems to be the Golgi [78]. Hachiya's report also indicated that $\mathrm{C} 1$ is predominantly seen at the cell surface, while full-length $\operatorname{PrP}^{\mathrm{C}}$ resides inside the cell, suggesting that full-length $\mathrm{PrP}^{\mathrm{C}}$ can be recycled. The 
internalization of $\mathrm{PrP}^{\mathrm{C}}$ in $\mathrm{N} 2 \mathrm{a}$ cells is relatively rapid as demonstrated by Morris's group, with more than $25 \%$ of the surface $\operatorname{PrP}^{\mathrm{C}}$ internalized within 10 minutes [79]. In conclusion, evidence indicates that $\mathrm{N} 2$ a cells exhibit proper intracellular trafficking of $\operatorname{PrP}^{\mathrm{C}}$, which may be required for $\operatorname{PrP}^{\mathrm{C}}$ to $\operatorname{PrP} \mathrm{P}^{\mathrm{Sc}}$ conversion.

In this scenario, prions (i.e. $\operatorname{PrP}^{\mathrm{Sc}}$ ) may enter cells by binding to $\operatorname{PrP}^{\mathrm{C}}$ on the cell surface and then $\operatorname{PrP}^{\mathrm{C}}$ transports prions (i.e. $\mathrm{PrP}^{\mathrm{Sc}}$ ) to the $\mathrm{PNC}$, which seems to be either an endosomal compartment or the Golgi. Whether the massive conversion to prion occurs at the cell surface or in the PNC is unknown, but Tabrizi's group reported strong detection of $\operatorname{PrP}^{\mathrm{Sc}}$ at the plasma membrane and in the PNC in murine N2a cells, suggesting that both are candidate locations for conversion. In addition, they suggested that prion conversion occurs at the cell surface within 1 min, indicating that strong association of exogenous $\operatorname{PrP}^{\mathrm{Sc}}$ with $\operatorname{PrP}^{\mathrm{C}}$ occurs at the plasma membrane [80]. However, artificial GPI-anchorless PrP expressed in transgenic mice on a $\operatorname{Prnp}^{0 / 0}$ background was still converted to $\operatorname{PrP}^{\mathrm{Sc}}$ after prion inoculation into the mice [12], indicating 1) that the conversion occurs in another compartment beyond the cell surface and 2) that there must be another endocytic pathway for $\operatorname{PrP}^{\mathrm{Sc}}$ to enter cells.

The $\alpha$-cleavage of $\operatorname{PrP}^{\mathrm{C}}$ may occur after expression on the surface, because both physiological and artificial GPI-anchorless PrPs are not cleaved [23]. Thus, if $\operatorname{PrP}^{\mathrm{C}}$ is cleaved to generate $\mathrm{C} 1, \mathrm{C} 1$ does not take prions to the intracellular compartment, since it does not seem to be internalized. We have also found that $\operatorname{PrP}^{\mathrm{C}}$ is rapidly internalized in $\mathrm{N} 2 \mathrm{a}$ cells, but not in $\mathrm{HpL} 3-4$ cells, which are competent and incompetent for prion infection, respectively (data not shown), although other group has shown that $\mathrm{PrP}^{\mathrm{C}}$ in HpL3-4 cells are rapidly internalized and $\mathrm{HpL}$ 3-4 cells are able to replicate prions [81]. HpL 3-4 cells that we obtained might have lost these phenotypes, suggesting that competent cells for prion propagation should have features of rapid $\operatorname{PrP}^{\mathrm{C}}$ internalization and $\mathrm{PrP}^{\mathrm{C}}$ accumulation in the Golgi. It would be interesting to check if other competent cell lines such as rat pheochromocytoma PC12, hypothalamic neuronal GT-1 cells, and the rabbit epithelial cell line RK13 [82] show similar endocytic features as $\mathrm{N} 2 \mathrm{a}$ cells.

The identity of the cellular proteases responsible for $\alpha$-cleavage seems to be important to address the location of $\alpha$-cleavage event. In 1992 and 1995, Prusiner's group suggested that a chymotryptic protease is responsible for the degradation of $\operatorname{PrP}^{\mathrm{C}}$ to generate $\operatorname{PrP}^{\mathrm{C}}$-II, because tosyl phenylalanyl chloromethyl ketone (TPCK), but not normal protease inhibitor cocktail, reduced the production of $\mathrm{PrP}^{\mathrm{C}}$-II $[19,20]$. Alternatively, Prelli's group reported in 1998 that the metal-chelating agents EDTA and EGTA show the highest activity to block $\alpha$-cleavage of $\operatorname{PrP}^{\mathrm{C}}$ [83], suggesting the involvement of metalloproteases, although the operative enzymes were not identified. In 2001, however, Checler's group [84] provided the first evidence implicating the responsible metalloproteases as the disintegrins ADAM10 (A disintegrin and metalloprotease) and TACE (tumor necrosis factor a-converting enzyme or ADAM17) by using an in vitro cell culture system and a pharmacological approach, although they failed to completely block the generation of C1 and N1. In 2011, however, Glatzel's group used neuron-specific Adam 10 knockout mice to show that ADAM10 does not have a direct role in the $\alpha$ cleavage of $\operatorname{PrP}^{\mathrm{C}}$, but rather it is responsible for the shedding of $\operatorname{PrP}^{\mathrm{C}}$ from the surface of cell [85]. ADAM9 and ADAM10 are likely both involved in the shedding of $\operatorname{PrP}^{\mathrm{C}}$ as supported by work from Hooper's group [86]. Recently, Kong's group demonstrated that ADAM8 is also a candidate for the $\alpha$ cleavage of $\operatorname{PrP}^{\mathrm{C}}$ [87]. Since mice with ADAM8 deficiency still exhibited residual $\mathrm{C} 1$ [87] and male 
and female Adam8 -/- mice were viable and fertile [88], compensatory mechanism may be involved. Collectively, much work remains to clarify the exact enzyme mediating $\alpha$-cleavage of $\operatorname{Pr} \mathrm{P}^{\mathrm{C}}$. The best evidence currently available suggests that metalloproteases are involved. Interestingly, involvement of an enzyme responsible for the generation of $\operatorname{PrP}^{\mathrm{Sc}}$ or $\mathrm{C} 2$, a pathogenic form of $\mathrm{PrP}^{\mathrm{C}}$, has also been suggested [43]. This study reported that pharmacological inhibitors of calpains, caspases, and the proteasome, prevented the production of $\mathrm{C} 2$, while lysosomal proteases were not involved. Thus, $\mathrm{C} 2$ as well as $\mathrm{C} 1$ might be generated via physiological machinery. This needs further investigation because calpain-like activity is also suggested in normal processing of $\operatorname{PrP}^{\mathrm{C}}$ [89].

\section{Conclusions}

Proteinse K (PK) treatment of brains infected with prions is the most convincing method to detect $\mathrm{PrP}^{\mathrm{Sc}}$. The PK treatment gives rise to an N-terminally truncated form, the size of which is around $\mathrm{Mr}$ 27,000-30,000 (PrP 27-30). C1 is a completely different N-terminally truncated form, which is derived from normal cellular $\operatorname{PrP}^{\mathrm{C}}$ and may have a physiological function. PrP27-30 is $\mathrm{PK}$ resistant and prionassociated, while $\mathrm{C} 1$ is $\mathrm{PK}$ sensitive and is the product of $\operatorname{PrP}^{\mathrm{C}} \alpha$-cleavage under normal condition. Recently several reports have shown the lack of detectable PK-resistant prion protein (PrPsen vs. PrPres) [90], but the infected host suffers from neurodegenerative dysfunction and the infectivity is transmissible $[44,91]$. These results demonstrate that pathogenic prion proteins are not always PKresistant or detectable. The byproduct of the " $\alpha$-cleavage phenomenon" is that PNGase $F$, which is able to remove almost all types of N-linked glycans, provides a valuable tool to detect both pathogenic $\mathrm{PrP}^{\mathrm{Sc}}$ and PK-sensitive PrPsen. In some cases, $\mathrm{PK}$ treatment might not be necessary to detect abnormal prion proteins, because normal $\operatorname{PrP}^{\mathrm{C}}$ shows only two bands, full-length $\operatorname{PrP}^{\mathrm{C}}$ and $\mathrm{C}$, , but brains of CJD patients show additional bands (i.e. C2) by PNGase F treatment alone [21].

It seems that there are at least two types of transgenic mouse models: " $\mathrm{PrP}^{\mathrm{Sc}}$ type" and " $\Delta \mathrm{F}$ type". The "PrP $\mathrm{P}^{\mathrm{Sc}}$ type" mice generate $\mathrm{PrP}$ aggregation and neuropathology that is transmissible to another host, while " $\Delta \mathrm{F}$ type" mice exhibit direct neurotoxicity, but it is counteracted by $\operatorname{PrP}^{\mathrm{C}}$. Whether a mutation is associated with the " $\Delta \mathrm{F}$ type" in humans is currently unknown. Alternatively, " $\Delta \mathrm{F}$ type" mutations mimic neurotoxic signals caused by prions $\left(\mathrm{PrP}^{\mathrm{Sc}}\right.$ or $\left.\mathrm{PrPsen}\right)$, since prions require endogenous $\operatorname{PrP}^{\mathrm{C}}$ to induce CNS dysfunction.

The " $\alpha$-cleavage phenomenon" provides an intriguing concept to improve our understanding of prion biology. When $\alpha$-cleavage is blocked by mutations, it may induce either toxic $\Delta \mathrm{F}$ type $\operatorname{PrP}$ or aggregated $\operatorname{PrP}$ such as $\operatorname{PrP}^{\mathrm{Sc}}$. Thus, $\alpha$-cleavage might be a protective mechanism to eliminate detrimental behavior of $\operatorname{PrP}^{\mathrm{C}}$, since anchorless $\mathrm{PrP}$ is not cleaved and therefore tends to aggregate when overexpressed [52]. This may explain why endogenous expression of anchorless $\operatorname{PrP}^{\mathrm{C}}$ is so minimal [23]. In addition, $\mathrm{C} 1$, a naturally occurring fragment of $\operatorname{PrP}^{\mathrm{C}}$, has been shown to protect from prion disease by acting as a dominant negative inhibitor of $\mathrm{PrP}^{\mathrm{Sc}}$ formation [92]. These reports enhance the importance of the " $\alpha$-cleavage phenomenon". Despite significant advances in recent years, substantially more research is necessary in the prion field. The interesting questions to be addressed in the future include: 1) What is the mechanism by which Dpl causes male sterility? 2) What is the normal function of Shadoo? 3) What enzymes are responsible to cleave $\mathrm{PrP}^{\mathrm{C}}$ or Shadoo? 4) Where 
does conversion from $\operatorname{PrP}^{\mathrm{C}}$ to $\operatorname{PrP}^{\mathrm{Sc}}$ occur? 5) Where does $\alpha$-cleavage occur? 6) What are the normal functions of $\mathrm{N} 1$ and $\mathrm{C} 1$ ? 7) What are the normal functions of anchorless PrP?

\section{Acknowledgments}

This work was supported in part by MHLW KAKENHI Grant Number H24-Iyaku-Shitei-029 and JSPS KAKENHI Grant Number C24590172. We thank Dr. Kerry S. Campbell, Fox Chase Cancer Center, Philadelphia, USA, for advice and critical review of the manuscript. We also thank Dr. Simon Milling, University of Glasgow, Institute of Infection, Immunity and Inflammation, Glasgow, Scotland, and Dr. Frank Baumann, Hertie Institute for Clinical Brain Research, for critical reading of the manuscript.

\section{Conflict of Interest}

The authors declare no conflict of interest.

\section{References and Notes}

1. Oesch, B.; Westaway, D.; Walchli, M.; McKinley, M.P.; Kent. S.B.; Aebersold, R.; Barry, R.A.; Tempst, P.; Teplow, D.B.; Hood, L.E.; et al. A cellular gene encodes scrapie PrP 27-30 protein. Cell 1985, 40, 735-746.

2. Prusiner, S.B. Novel proteinaceous infectious particles cause scrapie. Science 1982, 216, 136-144

3. Collinge, J.; Whittington, M.A.; Sidle, KC.; Smith, C.J.; Palmer, M.S.; Clarke, A.R.; Jefferys, J.G. Prion protein is necessary for normal synaptic function. Nature 1994, 370, 295-297.

4. Tobler, I.; Gaus, S.E.; Deboer, T.; Achermann, P.; Fischer, M.; Rulicke, T.; Moser, M.; Oesch, B.; McBride, P.A.; Manson, J.C. Altered circadian activity rhythms and sleep in mice devoid of prion protein. Nature 1996, 380, 639-642.

5. Ovadia, H.; Rosenmann, H.; Shezen, E.; Halimi, M.; Ofran, I.; Gabizon, R. Effect of scrapie infection on the activity of neuronal nitric-oxide synthase in brain and neuroblastoma cells. J.Biol.Chem. 1996, 271, 16856-16861.

6. Keshet, G.I.; Ovadia, H.; Taraboulos, A.; Gabizon, R. Scrapie-infected mice and PrP knockout mice share abnormal localization and activity of neuronal nitric oxide synthase. J.Neurochem. 1999, 72, 1224-1231.

7. Brown, P.B. lymphocytes and neuroinvasion. Nature 1997, 390, 662-663

8. Bueler, H.; Aguzzi, A.; Sailer, A.; Greiner, R.A.; Autenried, P.; Aguet, M.; Weissmann, C. Mice devoid of PrP are resistant to scrapie. Cell 1993, 73, 1339-1347.

9. Mallucci, G.R.; Ratte, S.; Asante, E.A.; Linehan, J.; Gowland, I.; Jefferys, J.G.; Collinge, J. Postnatal knockout of prion protein alters hippocampal CA1 properties, but does not result in neurodegeneration. EMBO J. 2002, 21, 202-210.

10. Brandner, S.; Isenmann, S.; Raeber, A.; Fischer, M.; Sailer, A.; Kobayashi, Y.; Marino, S.; Weissmann, C.; Aguzzi, A. Normal host prion protein necessary for scrapie-induced neurotoxicity. Nature 1996, 379, 339-343. 
11. Mallucci, G.; Dickinson, A.; Linehan, J.; Klohn, P.C.; Brandner, S.; Collinge, J. Depleting neuronal PrP in prion infection prevents disease and reverses spongiosis. Science 2003, 302, 871874.

12. Chesebro, B.; Trifilo, M.; Race, R.; Meade-White, K.; Teng, C.; LaCasse, R.; Raymond, L.; Favara, C.; Baron, G.; Priola, S.; et al. Anchorless prion protein results in infectious amyloid disease without clinical scrapie. Science 2005, 308, 1435-1439.

13. Sandberg, M.K.; Al-Doujaily, H.; Sharps, B.; Clarke, A.R.; Collinge, J. Prion propagation and toxicity in vivo occur in two distinct mechanistic phases. Nature 2011, 470, 540-542.

14. Basler, K.; Oesch, B.; Scott, M.; Westaway, D.; Walchli, M.; Groth, D.F.; McKinley, M.P.; Prusiner, S.B.; Weissmann, C. Scrapie and cellular PrP isoforms are encoded by the same chromosomal gene. Cell 1986, 46, 417-428.

15. Biasini, E.; Turnbaugh, J.A.; Unterberger, U.; Harris, D.A. Prion protein at the crossroads of physiology and disease. Trends Neurosci. 2012, 35, 92-103.

16. Nieznanski, K. Interactions of prion protein with intracellular proteins: so many partners and no consequences? Cell Mol.Neurobiol. 2010, 30, 653-666.

17. Linden, R.; Martins, V.R.; Prado, M.A.; Cammarota, M.; Izquierdo, I.; Brentani, R.R. Physiology of the prion protein. Physiol Rev. 2008, 88, 673-728.

18. van, R.T.; Smolenaars, M.M.; Madsen, O.; de Jong, W.W. Molecular evolution of the mammalian prion protein. Mol.Biol.Evol. 2003, 20, 111-121.

19. Pan, K.M.; Stahl, N.; Prusiner, S.B. Purification and properties of the cellular prion protein from Syrian hamster brain. Protein Sci. 1992, 1, 1343-1352.

20. Taraboulos, A.; Scott, M.; Semenov, A.; Avrahami, D.; Laszlo, L.; Prusiner, S.B. Cholesterol depletion and modification of $\mathrm{COOH}$-terminal targeting sequence of the prion protein inhibit formation of the scrapie isoform. J.Cell Biol. 1995, 129, 121-132.

21. Chen, S.G.; Teplow, D.B.; Parchi, P.; Teller, J.K.; Gambetti, P.; Autilio-Gambetti, L. Truncated forms of the human prion protein in normal brain and in prion diseases. J.Biol.Chem. 1995, 270, 19173-19180.

22. Harris, D.A.; Huber, M.T.; van, D.P.; Shyng, S.L.; Chait, B.T.; Wang, R. Processing of a cellular prion protein: identification of $\mathrm{N}-$ and $\mathrm{C}$-terminal cleavage sites. Biochemistry 1993, 32, 1009-1016.

23. Kikuchi, Y.; Kakeya, T.; Nakajima, O.; Sakai, A.; Ikeda, K.; Yamaguchi, N.; Yamazaki, T.; Tanamoto, K.; Matsuda, H.; Sawada, J.; et al. Hypoxia induces expression of a GPI-anchorless splice variant of the prion protein. FEBS J. 2008, 275, 2965-2976.

24. Syed, M.; Nourizadeh-Lillabadi, R.; Press, C.M.; Alestrom, P. Prion protein function and the disturbance of early embryonic development in zebrafish. Prion. 2011, 5, 88-92.

25. Campana, V.; Caputo, A.; Sarnataro, D.; Paladino, S.; Tivodar, S.; Zurzolo, C. Characterization of the properties and trafficking of an anchorless form of the prion protein. J.Biol.Chem. 2007, 282, 22747-22756.

26. Shmerling, D.; Hegyi, I.; Fischer, M.; Blattler, T.; Brandner, S.; Gotz., J.; Rulicke, T.; Flechsig, E.; Cozzio, A.; et al. Expression of amino-terminally truncated $\mathrm{PrP}$ in the mouse leading to ataxia and specific cerebellar lesions. Cell 1998, 93, 203-214. 
27. Hsiao, K.K.; Scott, M.; Foster, D.; Groth, D.F.; DeArmond, S.J.; Prusiner, S.B. Spontaneous neurodegeneration in transgenic mice with mutant prion protein. Science 1990, 250, 1587-1590.

28. Hsiao, K.K.; Groth, D.; Scott, M.; Yang, S.L.; Serban, H.; Rapp, D.; Foster, D.; Torchia, M.; Dearmond, S.J.; Prusiner, S.B. Serial transmission in rodents of neurodegeneration from transgenic mice expressing mutant prion protein. Proc.Natl.Acad.Sci.U.S.A 1994, 91, 9126-9130.

29. Telling, G.C.; Haga, T.; Torchia, M.; Tremblay, P.; DeArmond, S.J.; Prusiner, S.B. Interactions between wild-type and mutant prion proteins modulate neurodegeneration in transgenic mice. Genes Dev. 1996, 10, 1736-1750.

30. Oliveira-Martins, J.B.; Yusa, S.; Calella, A.M.; Bridel, C.; Baumann, F.; Dametto, P.; Aguzzi, A. Unexpected tolerance of alpha-cleavage of the prion protein to sequence variations. PLoS.One. 2010, 5, e9107.

31. Borchelt, D.R.; Davis, J.; Fischer, M.; Lee, M.K.; Slunt, H.H.; Ratovitsky, T.; Regard, J.; Copeland, N.G.; Jenkins, N.A.; Sisodia, S.S.; et al. A vector for expressing foreign genes in the brains and hearts of transgenic mice. Genet.Anal. 1996, 13, 159-163.

32. Fischer, M.; Rulicke, T.; Raeber, A.; Sailer, A.; Moser, M.; Oesch, B.; Brandner, S.; Aguzzi, A.; Weissmann, C. Prion protein (PrP) with amino-proximal deletions restoring susceptibility of PrP knockout mice to scrapie. EMBO J. 1996, 15, 1255-1264.

33. Baumann, F.; Tolnay, M.; Brabeck, C.; Pahnke, J.; Kloz, U.; Niemann, H.H.; Heikenwalder, M.; Rulicke, T.; Burkle, A.; Aguzzi, A. Lethal recessive myelin toxicity of prion protein lacking its central domain. EMBO J. 2007, 26, 538-547.

34. Muramoto, T.; Scott, M.; Cohen, F.E.; Prusiner, S.B. Recombinant scrapie-like prion protein of 106 amino acids is soluble. Proc.Natl.Acad.Sci.U.S.A 1996, 93, 15457-15462.

35. Holscher, C.; Delius, H.; Burkle, A. Overexpression of nonconvertible PrPc delta114-121 in scrapie-infected mouse neuroblastoma cells leads to trans-dominant inhibition of wild-type $\operatorname{PrP}(\mathrm{Sc})$ accumulation. J.Virol. 1998, 72, 1153-1159.

36. Li, A.; Christensen, H.M.; Stewart, L.R.; Roth, K.A.; Chiesa, R.; Harris, D.A. Neonatal lethality in transgenic mice expressing prion protein with a deletion of residues 105-125. EMBO J. 2007, 26, 548-558.

37. Chiesa, R.; Piccardo, P.; Quaglio, E.; Drisaldi, B.; Si-Hoe, S.L.; Takao, M.; Ghetti, B.; Harris, D.A. Molecular distinction between pathogenic and infectious properties of the prion protein. J.Virol. 2003, 77, 7611-7622.

38. Chiesa, R.; Piccardo, P.; Ghetti, B.; Harris, D.A. Neurological illness in transgenic mice expressing a prion protein with an insertional mutation. Neuron 1998, 21, 1339-1351.

39. Jackson, W.S.; Borkowski, A.W.; Faas, H.; Steele, A.D.; King, O.D.; Watson, N.; Jasanoff, A.; Lindquist, S. Spontaneous generation of prion infectivity in fatal familial insomnia knockin mice. Neuron 2009, 63, 438-450.

40. Dossena, S.; Imeri, L.; Mangieri, M.; Garofoli, A.; Ferrari, L.; Senatore, A.; Restelli, E.; Balducci, C.; Fiordaliso, F.; Salio, M.; et al. Mutant prion protein expression causes motor and memory deficits and abnormal sleep patterns in a transgenic mouse model. Neuron 2008, 60, 598-609.

41. Yang, W.; Cook, J.; Rassbach, B.; Lemus, A.; DeArmond, S.J.; Mastrianni, J.A. A New Transgenic Mouse Model of Gerstmann-Straussler-Scheinker Syndrome Caused by the A117V Mutation of PRNP. J.Neurosci. 2009, 29, 10072-10080. 
42. Bian, J.; Nazor, K.E.; Angers, R.; Jernigan, M.; Seward, T.; Centers, A.; Green, M.; Telling, G.C. GFP-tagged PrP supports compromised prion replication in transgenic mice. Biochem.Biophys.Res.Commun. 2006, 340, 894-900.

43. Yadavalli, R.; Guttmann, R.P.; Seward, T.; Centers, A.P.; Williamson, R.A.; Telling, G.C. Calpain-dependent endoproteolytic cleavage of PrPSc modulates scrapie prion propagation. J.Biol.Chem. 2004, 279, 21948-21956.

44. Nazor, K.E.; Kuhn, F.; Seward, T.; Green, M.; Zwald, D.; Purro, M.; Schmid, J.; Biffiger, K.; Power, A.M.; Oesch, B.; et al. Immunodetection of disease-associated mutant PrP, which accelerates disease in GSS transgenic mice. EMBO J. 2005, 24, 2472-2480.

45. Hegde, R.S.; Mastrianni, J.A.; Scott, M.R.; DeFea, K.A.; Tremblay, P.; Torchia, M.; DeArmond, S.J.; Prusiner, S.B.; Lingappa, V.R. A transmembrane form of the prion protein in neurodegenerative disease. Science 1998, 279, 827-834.

46. Hegde, R.S.; Tremblay, P.; Groth, D.; DeArmond, S.J.; Prusiner, S.B.; Lingappa, V.R. Transmissible and genetic prion diseases share a common pathway of neurodegeneration. Nature 1999, 402, 822-826.

47. Westergard, L.; Turnbaugh, J.A.; Harris, D.A. A nine amino acid domain is essential for mutant prion protein toxicity. J.Neurosci. 2011, 31, 14005-14017.

48. Li, A.; Piccardo, P.; Barmada, S.J.; Ghetti, B.; Harris, D.A. Prion protein with an octapeptide insertion has impaired neuroprotective activity in transgenic mice. EMBO J. 2007, 26, 2777-2785

49. Muramoto, T.; DeArmond, S.J.; Scott, M.; Telling, G.C.; Cohen, F.E.; Prusiner, S.B. Heritable disorder resembling neuronal storage disease in mice expressing prion protein with deletion of an alpha-helix. Nat.Med. 1997, 3, 750-755.

50. Atarashi, R.; Nishida, N.; Shigematsu, K.; Goto, S.; Kondo, T.; Sakaguchi, S.; Katamine, S. Deletion of N-terminal residues 23-88 from prion protein $(\mathrm{PrP})$ abrogates the potential to rescue PrP-deficient mice from PrP-like protein/doppel-induced Neurodegeneration. J.Biol.Chem. 2003, 278, 28944-28949.

51. Race, B.; Meade-White, K.; Race, R.; Baumann, F.; Aguzzi, A.; Chesebro, B. Prion protein on astrocytes or in extracellular fluid impedes neurodegeneration induced by truncated prion protein. Exp.Neurol. 2009, 217, 347-352.

52. Stohr, J.; Watts, J.C.; Legname, G.; Oehler, A.; Lemus, A.; Nguyen, HO.; Sussman, J.; Wille, H.; DeArmond, S.J.; Prusiner, S.B.; et al. Spontaneous generation of anchorless prions in transgenic mice. Proc.Natl.Acad.Sci.U.S.A 2011, 108, 21223-21228.

53. Bueler, H.; Fischer, M.; Lang, Y.; Bluethmann, H.; Lipp, H.P.; DeArmond, S.J.; Prusiner, S.B.; Aguet, M.; Weissmann, C. Normal development and behaviour of mice lacking the neuronal cellsurface PrP protein. Nature 1992, 356, 577-582.

54. Moore, R.C.; Lee, I.Y.; Silverman, G.L.; Harrison, P.M.; Strome, R.; Heinrich, C.; Karunaratne, A.; Pasternak, S.H.; Chishti, M.A.; Liang, Y.; et al. Ataxia in prion protein (PrP)-deficient mice is associated with upregulation of the novel PrP-like protein doppel. J.Mol.Biol. 1999, 292, $797-$ 817.

55. Manson, J.C.; Clarke, A.R.; Hooper, M.L.; Aitchison, L.; McConnell, I.; Hope, J.; 129/Ola mice carrying a null mutation in PrP that abolishes mRNA production are developmentally normal. Mol.Neurobiol. 1994, 8, 121-127. 
56. Sakaguchi, S.; Katamine, S.; Nishida, N.; Moriuchi, R.; Shigematsu, K.; Sugimoto, T.; Nakatani, A.; Kataoka, Y.; Houtani, T.; Shirabe, S.; et al. Loss of cerebellar Purkinje cells in aged mice homozygous for a disrupted PrP gene. Nature 1996, 380, 528-531.

57. Kuwahara, C.; Takeuchi, A.M.; Nishimura, T.; Haraguchi, K.; Kubosaki, A.; Matsumoto, Y.; Saeki, K.; Matsumoto, Y.; Yokoyama, T.; Itohara, S.; et al. Prions prevent neuronal cell-line death. Nature 1999, 400, 225-226.

58. Rossi, D.; Cozzio, A.; Flechsig, E.; Klein, M.A.; Rulicke, T.; Aguzzi, A.; Weissmann, C. Onset of ataxia and Purkinje cell loss in PrP null mice inversely correlated with Dpl level in brain. EMBO J. 2001, 20, 694-702.

59. Behrens, A.; Genoud, N.; Naumann, H.; Rulicke, T.; Janett, F.; Heppner, F.L.; Ledermann, B.; Aguzzi, A. Absence of the prion protein homologue Doppel causes male sterility. EMBO J. 2002, 21, 3652-3658.

60. Paisley, D.; Banks, S.; Selfridge, J.; McLennan, N.F.; Ritchie, A.M.; McEwan, C.; Irvine, D.S.; Saunders, P.T.; Manson, J.C.; Melton, D.W. Male infertility and DNA damage in Doppel knockout and prion protein/Doppel double-knockout mice. Am.J.Pathol. 2004, 164, 2279-2288.

61. Mo, H.; Moore, R.C.; Cohen, F.E.; Westaway, D.; Prusiner, S.B.; Wright, P.E.; Dyson, H.J. Two different neurodegenerative diseases caused by proteins with similar structures. Proc.Natl.Acad.Sci.U.S.A 2001, 98, 2352-2357.

62. Silverman, G.L.; Qin, K.; Moore, R.C.; Yang, Y.; Mastrangelo, P.; Tremblay, P.; Prusiner, S.B.; Cohen, F.E.; Westaway, D. Doppel is an N-glycosylated, glycosylphosphatidylinositol-anchored protein. Expression in testis and ectopic production in the brains of $\operatorname{Prnp}(0 / 0)$ mice predisposed to Purkinje cell loss. J.Biol.Chem. 2000, 275, 26834-26841.

63. Peoc'h, K.; Serres, C.; Frobert, Y.; Martin, C.; Lehmann, S.; Chasseigneaux, S.; Sazdovitch, V.; Grassi, J.; Jouannet, P.; Launay, J.M.; et al. The human "prion-like" protein Doppel is expressed in both Sertoli cells and spermatozoa. J.Biol.Chem. 2002, 277, 43071-43078.

64. Rognoni, P.; Chiarelli, L.R.; Comincini, S.; Azzalin, A.; Miracco, C.; Valentini, G. Biochemical signatures of doppel protein in human astrocytomas to support prediction in tumor malignancy. J.Biomed.Biotechnol. 2010, 2010, 301067.

65. Baumann, F.; Pahnke, J.; Radovanovic, I.; Rulicke, T.; Bremer, J.; Tolnay, M.; Aguzzi, A. Functionally relevant domains of the prion protein identified in vivo. PLoS.One. 2009, 4, e6707.

66. Premzl, M.; Sangiorgio, L.; Strumbo, B.; Marshall Graves, J.A.; Simonic, T.; Gready, J.E. Shadoo, a new protein highly conserved from fish to mammals and with similarity to prion protein. Gene 2003, 314, 89-102.

67. Uboldi, C.; Paulis, M.; Guidi, E.; Bertoni, A.; Meo, G.P.; Perucatti, A.; Iannuzzi, L.; Raimondi, E.; Brunner, R.M.; Eggen, A.; et al. Cloning of the bovine prion-like Shadoo (SPRN) gene by comparative analysis of the predicted genomic locus. Mamm.Genome 2006, 17, 1130-1139.

68. Watts, J.C.; Drisaldi, B.; Ng, V.; Yang, J.; Strome, B.; Horne, P.; Sy, M.S.; Yoong, L.; Young, R.; Mastrangelo, P.; et al. The CNS glycoprotein Shadoo has $\operatorname{PrP}(\mathrm{C})$-like protective properties and displays reduced levels in prion infections. EMBO J. 2007, 26, 4038-4050.

69. Young, R.; Passet, B.; Vilotte, M.; Cribiu, E.P.; Beringue, V.; Le, P.F.; Laude, H.; Vilotte, J.L. The prion or the related Shadoo protein is required for early mouse embryogenesis. FEBS Lett. 2009, 583, 3296-3300. 
70. Daude, N.; Wohlgemuth, S.; Brown, R.; Pitstick, R.; Gapeshina, H.; Yang, J.; Carlson, G.A.; Westaway D. Knockout of the prion protein (PrP)-like Sprn gene does not produce embryonic lethality in combination with PrPC-deficiency. Proc.Natl.Acad.Sci.U.S.A 2012, 109, 9035-9040.

71. Prusiner, S.B. Molecular biology of prion diseases. Science 1991, 252, 1515-1522.

72. Borchelt, D.R.; Scott, M.; Taraboulos, A.; Stahl, N.; Prusiner, S.B. Scrapie and cellular prion proteins differ in their kinetics of synthesis and topology in cultured cells. J.Cell Biol. 1990, 110, $743-752$.

73. Taraboulos, A.; Serban, D.; Prusiner, S.B. Scrapie prion proteins accumulate in the cytoplasm of persistently infected cultured cells. J.Cell Biol. 1990, 110, 2117-2132.

74. Caughey, B.; Raymond, G.J. The scrapie-associated form of PrP is made from a cell surface precursor that is both protease- and phospholipase-sensitive. J.Biol.Chem. 1991, 266, 18217-18223.

75. Klohn, P.C.; Stoltze, L.; Flechsig, E.; Enari, M.; Weissmann, C. A quantitative, highly sensitive cell-based infectivity assay for mouse scrapie prions. Proc.Natl.Acad.Sci.U.S.A 2003, 100, 11666-11671.

76. Prado, M.A.; Alves-Silva, J.; Magalhaes, A.C.; Prado, V.F.; Linden, R.; Martins, V.R.; Brentani, R.R. PrPc on the road: trafficking of the cellular prion protein. J.Neurochem. 2004, 88, 769-781.

77. Shyng, S.L.; Huber, M.T.; Harris, D.A. A prion protein cycles between the cell surface and an endocytic compartment in cultured neuroblastoma cells. J.Biol.Chem. 1993, 268, 15922-15928.

78. Hachiya, N.S.; Watanabe, K.; Sakasegawa, Y.; Kaneko, K. Microtubules-associated intracellular localization of the NH2-terminal cellular prion protein fragment. Biochem.Biophys.Res.Commun. 2004, 313, 818-823.

79. Sunyach, C.; Jen, A.; Deng, J.; Fitzgerald, K.T.; Frobert, Y.; Grassi, J.; McCaffrey, M.W.; Morris, R. The mechanism of internalization of glycosylphosphatidylinositol-anchored prion protein. EMBO J. 2003, 22, 3591-3601.

80. Goold, R.; Rabbanian, S.; Sutton, L.; Andre, R.; Arora, P.; Moonga, J.; Clarke, A.R.; Schiavo, G.; Jat, P.; Collinge, J.; et al. Rapid cell-surface prion protein conversion revealed using a novel cell system. Nat.Commun. 2011, 2, 281.

81. Maas, E.; Geissen, M.; Groschup, M.H.; Rost, R.; Onodera, T.; Schatzl, H.; Vorberg, I.M. Scrapie infection of prion protein-deficient cell line upon ectopic expression of mutant prion proteins. J.Biol.Chem. 2007, 282, 18702-18710.

82. Arellano-Anaya, Z.E.; Savistchenko, J.; Mathey, J.; Huor, A.; Lacroux, C.; Andreoletti, O.; Vilette, D. A simple, versatile and sensitive cell-based assay for prions from various species. PLoS.One. 2011, 6, e20563.

83. Jimenez-Huete, A.; Lievens, P.M.; Vidal, R.; Piccardo, P.; Ghetti, B.; Tagliavini, F.; Frangione, B.; Prelli, F. Endogenous proteolytic cleavage of normal and disease-associated isoforms of the human prion protein in neural and non-neural tissues. Am.J.Pathol. 1998, 153, 1561-1572.

84. Vincent, B.; Paitel, E.; Saftig, P.; Frobert, Y.; Hartmann, D.; De, S.B.; Grassi, J.; Lopez-Perez, E.; Checler, F. The disintegrins ADAM10 and TACE contribute to the constitutive and phorbol esterregulated normal cleavage of the cellular prion protein. J.Biol.Chem. 2001, 276, 37743-37746.

85. Altmeppen, H.C.; Prox, J.; Puig, B.; Kluth, M.A.; Bernreuther, C.; Thurm, D.; Jorissen, E.; Petrowitz, B.; Bartsch, U.; De, S.B.; et al. Lack of a-disintegrin-and-metalloproteinase ADAM10 
leads to intracellular accumulation and loss of shedding of the cellular prion protein in vivo. Mol.Neurodegener. 2011, 6, 36.

86. Taylor, D.R.; Parkin, E.T.; Cocklin, S.L.; Ault, J.R.; Ashcroft, A.E.; Turner, A.J.; Hooper, N.M. Role of ADAMs in the ectodomain shedding and conformational conversion of the prion protein. J.Biol.Chem. 2009, 284, 22590-22600.

87. Liang, J.; Wang, W.; Sorensen, D.; Medina, S.; Ilchenko, S.; Kiselar, J.; Surewicz, W.K.; Booth, S.A.; Kong, Q. Cellular prion protein regulates its own alpha-cleavage through ADAM8 in skeletal muscle. J.Biol.Chem. 2012, 287, 16510-16520.

88. Kelly, K.; Hutchinson, G.; Nebenius-Oosthuizen, D.; Smith, A.J.; Bartsch, J.W.; Horiuchi, K.; Rittger, A.; Manova, K.; Docherty, A.J.; Blobel, C.P. Metalloprotease-disintegrin ADAM8: expression analysis and targeted deletion in mice. Dev.Dyn. 2005, 232, 221-231.

89. Hachiya, N.; Komata, Y.; Harguem, S.; Nishijima, K.; Kaneko, K. Possible involvement of calpain-like activity in normal processing of cellular prion protein. Neurosci.Lett. 2011, 490, $150-155$.

90. Safar, J.G.; Geschwind, M.D.; Deering, C.; Didorenko, S.; Sattavat, M.; Sanchez, H.; Serban, A.; Vey, M.; Baron, H.; Giles, K.; et al. Diagnosis of human prion disease. Proc.Natl.Acad.Sci.U.S.A 2005, 102, 3501-3506.

91. Sajnani, G.; Silva, C.J.; Ramos, A.; Pastrana, M.A.; Onisko, B.C.; Erickson, M.L.; Antaki, E.M.; Dynin, I.; Vazquez-Fernandez, E.; Sigurdson, C.J.; et al. PK-sensitive PrP is infectious and shares basic structural features with PK-resistant PrP. PLoS.Pathog. 2012, 8, e1002547.

92. Westergard, L.; Turnbaugh, J.A.; Harris, D.A. A naturally occurring C-terminal fragment of the prion protein (PrP) delays disease and acts as a dominant-negative inhibitor of PrPSc formation. J.Biol.Chem. 2011, 286, 44234-44242.

(C) 2012 by the authors; licensee MDPI, Basel, Switzerland. This article is an open access article distributed under the terms and conditions of the Creative Commons Attribution license (http://creativecommons.org/licenses/by/3.0/). 